\title{
Effects of Sleep and Wake on Oligodendrocytes and Their Precursors
}

\author{
Michele Bellesi, ${ }^{1}$ Martha Pfister-Genskow, ${ }^{1}$ Stephanie Maret, ${ }^{1}$ Sunduz Keles, ${ }^{2}$ Giulio Tononi, ${ }^{1}$ and Chiara Cirelli ${ }^{1}$ \\ Departments of ${ }^{1}$ Psychiatry and ${ }^{2}$ Biostatistics and Medical Informatics, University of Wisconsin-Madison, Madison, Wisconsin 53719
}

Previous studies of differential gene expression in sleep and wake pooled transcripts from all brain cells and showed that several genes expressed at higher levels during sleep are involved in the synthesis/maintenance of membranes in general and of myelin in particular, a surprising finding given the reported slow turnover of many myelin components. Other studies showed that oligodendrocyte precursor cells (OPCs) are responsible for the formation of new myelin in both the injured and the normal adult brain, and that glutamate released from neurons, via neuron-OPC synapses, can inhibit OPC proliferation and affect their differentiation into myelin-forming oligodendrocytes. Because glutamatergic transmission is higher in wake than in sleep, we asked whether sleep and wake can affect oligodendrocytes and OPCs. Using the translating ribosome affinity purification technology combined with microarray analysis in mice, we obtained a genome-wide profiling of oligodendrocytes after sleep, spontaneous wake, and forced wake (acute sleep deprivation). We found that hundreds of transcripts being translated in oligodendrocytes are differentially expressed in sleep and wake: genes involved in phospholipid synthesis and myelination or promoting OPC proliferation are transcribed preferentially during sleep, while genes implicated in apoptosis, cellular stress response, and OPC differentiation are enriched in wake. We then confirmed through BrdU and other experiments that OPC proliferation doubles during sleep and positively correlates with time spent in REM sleep, whereas OPC differentiation is higher during wake. Thus, OPC proliferation and differentiation are not perfectly matched at any given circadian time but preferentially occur during sleep and wake, respectively.

\section{Introduction}

Brain gene expression changes significantly between sleep and wake, and wake-related and sleep-related mRNAs belong to different functional categories (Cirelli, 2009). Several transcripts expressed at higher levels during sleep are involved in the synthesis/ maintenance of membranes in general and of myelin in particular (Cirelli et al., 2004; Mongrain et al., 2010). These results are surprising because they were based on comparisons between animals that had been asleep or awake for a few hours, whereas the turnover of most myelin components is reported to occur across many days (Baumann and Pham-Dinh, 2001). However, those studies had limitations because they pooled transcripts from all brain cells, whereas in situ hybridization experiments suggest that the effects of sleep and wake can vary significantly depending on cell type (Thompson et al., 2010). Another limitation was the exclusive focus on mRNA levels, which are not always predictive of protein levels (Waters et al., 2006; Bitton et al., 2008). Proteins, not DNA or RNA, carry out most cellular functions, but pro-

\footnotetext{
Received 0ct. 31, 2012; revised July 10, 2013; accepted July 15, 2013.

Author contributions: M.B., G.T., and C.C. designed research; M.B., M.P.-G., and S.M. performed research; M.B., M.P.-G., and S.K. analyzed data; M.B., G.T., and C.C. wrote the paper.

This work was supported by departmental funds to C.C. We thank Drs. Joe Dougherty, Myriam Heiman, and Nathaniel Heintz for help in implementing the TRAP method and Drs. Luisa de Vivo, Ugo Faraguna, and Aaron B. Nelson for help with behavioral and immunocytochemical studies.

The authors declare no competing financial interests.

Correspondence should be addressed to Dr. Chiara Cirelli, Department of Psychiatry, University of Wisconsin-

Madison, 6001 Research Park Boulevard, Madison, WI 53719. E-mail: ccirelli@wisc.edu.

S. Maret's present address: University of Geneva, 1211 Geneva 4, Switzerland.

DOI:10.1523/JNEUROSCI.5102-12.2013

Copyright $\odot 2013$ the authors $\quad 0270-6474 / 13 / 3314288-13 \$ 15.00 / 0$
}

teomic analysis remains challenging (Naidoo, 2011), and only a few brain proteins modulated by sleep and wake have been identified (Cirelli et al., 2009).

Oligodendrocyte precursor cells (OPCs) have intriguing properties (Nishiyama et al., 2009; Mangin and Gallo, 2011; Richardson et al., 2011). They are abundant both in the developing and mature CNS (Rivers et al., 2008), and mediate myelin formation in response to injury and in the normal brain (Polito and Reynolds, 2005; Rivers et al., 2008; Richardson et al., 2011). Importantly, glutamate release from neurons generates AMPAmediated excitatory currents in OPCs and inhibits their proliferation in a dose-dependent manner, suggesting that neuronal activity can affect myelination and possibly other still unknown functions of OPCs (Nishiyama et al., 2009; Mangin and Gallo, 2011; Richardson et al., 2011). We recently showed that cortical extracellular glutamate levels increase during wake and decline during most of sleep (Dash et al., 2009), and the expression of synaptic-enriched GluR1-containing AMPA receptors (Vyazovskiy et al., 2008) and their currents (Lante et al., 2011) increases during wake and decreases during sleep. However, whether sleep and wake can affect the number and turnover of OPCs is unknown.

Here we used the translating ribosome affinity purification (TRAP) technology combined with microarray analysis to obtain a genome-wide mRNA profiling of oligodendrocytes as a function of sleep, wake, and acute sleep deprivation. The TRAP methodology involves cell-specific expression of an eGFP-L10a ribosomal transgene to tag polysomes and immunoaffinity purify mRNAs. Thus, in addition to targeting specific cell groups, this 
method isolates mRNAs attached to ribosomes, providing an almost "translational" view of cellular function (Doyle et al., 2008). We find that the expression of hundreds of transcripts translated in oligodendrocytes changes because of sleep and wake, and many wake-related and sleep-related genes have complementary or opposite functions. We also find that some differentially expressed genes are enriched in premature oligodendrocytes, and we provide direct evidence that the proliferation of OPCs is negatively impacted by wake but doubles during sleep whereas their differentiation is enhanced by wake.

\section{Materials and Methods}

Animals. Adult (9-10 weeks old, of either sex) heterozygous 2' $3^{\prime}$-cyclicnucleotide $3^{\prime}$-phosphodiesterase (CNP)-eGFP-L10a bacterial artificial chromosome (BAC) transgenic mice and wild-type littermates were used in this study. Heterozygous offspring were obtained from homozygous CNP-eGFP BAC transgenic mice bred with C57BL/6 wild-type mice. All animal procedures followed the National Institutes of Health Guide for the Care and Use of Laboratory Animals, and facilities were reviewed and approved by the Institutional Animal Care and Use Committee of the University of Wisconsin-Madison, and were inspected and accredited by Association for Assessment and Accreditation of Laboratory Animal Care.

EEG recordings. Under deep isoflurane anesthesia (1-1.5\% volume), mice $(n=5)$ were implanted bilaterally for chronic EEG recordings with epidural screw electrodes over the frontal (from bregma: anteroposterior, $+1 \mathrm{~mm}$, mediolateral, $+1 \mathrm{~mm}$ ) and parietal cortex (anteroposterior, $-2 \mathrm{~mm}$; mediolateral, $+2 \mathrm{~mm}$ ) and cerebellum (reference electrode and ground). Electrodes were fixed to the skull with dental cement. Two stainless steel wires (diameter $0.4 \mathrm{~mm}$ ) were inserted into neck muscles to record the EMG. After surgery, mice were housed individually in transparent Plexiglas cages $(36.5 \times 25 \times 46 \mathrm{~cm})$ and kept in soundproof recording boxes for the duration of the experiment. Light and temperature were kept constant (LD 12:12, light on at 8:00 A.M., $23 \pm 1{ }^{\circ} \mathrm{C}$; food and water were available ad libitum and replaced daily at 8:00 A.M.). Approximately $7 \mathrm{~d}$ were allowed for recovery after surgery, and recordings were started only after the sleep-wake cycle had completely normalized. Mice were connected by a flexible cable to a commutator (Airflyte) and recorded continuously for 2 weeks using a Grass mod 8 polygraph (Grass Instruments). EEG and EMG signals were amplified and filtered as follows: EEG, high-pass filter at $0.1 \mathrm{~Hz}$, low-pass filter at $35 \mathrm{~Hz}$; EMG, high-pass filter at $10 \mathrm{~Hz}$, low-pass filter at $100 \mathrm{~Hz}$. All signals were digitalized at $128 \mathrm{~Hz}$ and stored on a computer. EEG power spectra were computed by a fast Fourier transform routine for $4 \mathrm{~s}$ epochs $(0.25 \mathrm{~Hz}$ resolution). Wake, nonrapid eye movement (NREM) sleep, and REM sleep were manually scored off-line (SleepSign, Kissei Comtec) in $4 \mathrm{~s}$ epochs according to standard criteria. Epochs containing artifacts, predominantly during active wake, were excluded from spectral analysis. Vigilance state could always be determined. Sleep deprivation began at light onset and was performed for $4 \mathrm{~h}$ by exposing the animals to a variety of novel objects, by transferring bedding material between cages, and by tapping on the cage whenever the mice appeared inactive and slow waves became evident on real-time EEG monitoring. Mice were never disturbed when they were spontaneously awake, feeding, or drinking.

Video monitoring of sleep/wake. Video recordings were performed continuously with infrared cameras (OptiView Technologies), stored in real time (AVerMedia Technologies), and used to determine the behavioral state of mice used for TRAP/array, immunocytochemistry, and Western blot analysis, to avoid risks of tissue lesion and inflammation resulting from the implant of EEG electrodes. We previously demonstrated that, although video monitoring cannot distinguish NREM sleep from REM sleep, it consistently estimates total sleep time with $\geq 90 \%$ accuracy (Maret et al., 2011). Motor activity was quantified by custom-made videobased motion detection algorithms with a time resolution of $1 \mathrm{~s}$ (MATLAB, MathWorks). The program detected animal motion every second within a previously set monitored area (corresponding to the cage area), by calculating the numbers of pixels whose intensity changed over time. Mice were collected only if they met stringent criteria for sleep/ wake: awake mice were killed during the dark period (at 3-5:00 A.M.) at the end of a long period of wake ( $>1 \mathrm{~h}$, interrupted by periods of sleep of $<5 \mathrm{~min}$ ), and after spending at least $70 \%$ of the previous $6-7 \mathrm{~h}$ awake. Sleeping mice were killed during the light phase (at $\sim 3: 00-5: 00$ P.M.), at the end of a long period of sleep ( $>45 \mathrm{~min}$, interrupted by periods of wake of $<4 \mathrm{~min}$ ), and after spending at least $75 \%$ of the previous $6-7 \mathrm{~h}$ asleep. Sleep-deprived mice were spontaneously awake during most of the dark phase and then maintained awake during the light period for 4-8 h (depending on the experiment) by exposure to novel objects. During this period, mice had continuous access to a running wheel.

Immunocytochemistry. Mice were deeply anesthetized with isoflurane $(1-1.5 \%$ volume $)$ and perfused transcardially with a flush $(\sim 30 \mathrm{~s})$ of saline followed by $4 \%$ paraformaldehyde in phosphate buffer (PB). Brains were removed, postfixed in the same fixative for $2 \mathrm{~h}$ (overnight for $\operatorname{PDGFR} \alpha$ ), and cut on a Vibratome in $50 \mu \mathrm{m}$ coronal sections, which were collected in PB in serial groups of 5 and then used for immunocytochemistry. Sections were rinsed in a blocking solution (normal goat serum [NGS] $1.5 \%$ and $0.3 \%$ Triton X-100 for CNP, NGS 5\%, and $0.1 \%$ Triton X-100 for Neun, GFAP, and PDGFR $\alpha$ ) for $1 \mathrm{~h}$, and then incubated overnight $\left(4^{\circ} \mathrm{C}\right)$ in the same blocking solution containing anti-GFP $(1$ : 500, Invitrogen, A21311) and one of the following primary antibodies (anti-CNP, 1:200, Millipore, MAB326; anti-NeuN, 1:200, Millipore, MAB377; anti-GFAP, 1:500, Sigma, G3893; anti-PDGFR $\alpha$, 1:500, Santa Cruz Biotechnology, sc-338). Sections were then exposed for $1.5 \mathrm{~h}$ to NGS (1.5\%) solution containing a mixture of AlexaFluor-568 (1:250, Invitrogen) and AlexaFluor-488 (1:250, Invitrogen) conjugated secondary antibodies. Sections were washed, mounted, air-dried, and coverslipped using Vectashield mounting medium (H-1000; Vector), and examined with a confocal microscope (Prairie Technologies). Control experiments with single-labeled sections and sections incubated with two primary antibodies and one secondary antibody or with one primary and two secondary antibodies revealed neither bleed-through nor crossreactivity. For O4 experiments, brains were immediately cut after perfusion and sections were quickly rinsed with a blocking solution containing the primary antibodies (anti-O4, 1:100, Millipore, MAB345 and anti-NG2, 1:1000, a gift from Dr. W. Stallcup, The Burnham Institute, La Jolla, CA). Triton X-100 was omitted because of the lipid composition of the O4 antigen, and anti-NG2 was used in substitution of anti-PDGFR $\alpha$ to identify OPCs (Dawson et al., 2003) because immunostaining with anti-PDGFR $\alpha$ was suboptimal in weakly fixed sections and in absence of Triton X-100. Microscopic fields were randomly selected as $512 \times 512$ pixel images (pixel size, $581 \mathrm{~nm}$ ) and observed with a UPlan FL $\mathrm{N} \times 40$ objective (numerical aperture, 1.3). To improve signal/noise ratio, 4 frames of each image were averaged. For eGFP and CNP/GFAP/NeuN/PDGFR $\alpha$ double-staining studies, fields were taken from frontal neocortex ( $n=3$ mice, 3 sections/mouse). For PDGFR $\alpha$ cell counting, sections were collected from 4 groups of animals: $\sim 6$ h of sleep (S, $n=6$ ), $6 \mathrm{~h}$ of sleep deprivation (SD, $n=6$ ), $\sim 6 \mathrm{~h}$ of spontaneous wake $(\mathrm{W}, n=6)$, and $6 \mathrm{~h}$ of recovery sleep after $6 \mathrm{~h}$ of sleep deprivation (RS, $n=6$ ). For O4 cell counting, sections were collected from sleeping $(n=6)$ and sleep-deprived $(n=5)$ mice. For both PDGFR $\alpha$ and $\mathrm{O}^{+}{ }^{+}$cells counting, fields were taken from frontal neocortex (layers V-VI, 3 sections/mouse). Image processing and cell-counting was performed on ImageJ and Photoshop CS2 (Adobe Systems).

Western blotting. Under anesthesia sleeping and sleep-deprived mice (12 S and 12 SD, 3 independent experiments, $4 \mathrm{~S}$ and 4 SD/experiment) were decapitated, and the forebrain region (cortex + basal ganglia + thalamus + hypothalamus) was quickly collected, immediately frozen on dry ice, and stored at $-80^{\circ} \mathrm{C}$. Samples were homogenized in ice-cold homogenization buffer (10 mm HEPES, Sigma/1.0 mm EDTA, Promega/ 2.0 mm EGTA, Bioston BioProducts/0.5 mm DTT, Invitrogen/0.1 mM PMSF, Fluka/Protease Inhibitor Cocktail, Roche/100 nм microcystin, Alexis) using a glass/glass tissue homogenizer (Knots). A fraction $(\sim 10 \%)$ of the homogenate from each sample was boiled in 10\% SDS for $10 \mathrm{~min}$ and stored unprocessed at $-80^{\circ} \mathrm{C}$. Protein concentration was determined by the bicinchonic acid assay (Pierce). Because the expression of housekeeping proteins, such as actin and tubulin, is affected by sleep and wake (Cirelli et al., 2004; Mackiewicz et al., 2007; Mongrain et al., 2010), a loading control was not used. Instead, homogenates from S and SD animals were loaded onto the same gels in 3-6 replicates, and 
experiments were repeated 3 times using three completely independent groups of animals. Equal amounts $(15 \mu \mathrm{g})$ of homogenate from each animal were first separated by Tris- $\mathrm{HCl}$ gel electrophoresis (Bio-Rad) in $1 \times$ Tris/glycine/SDS buffer (Bio-Rad), transferred to $0.45 \mu \mathrm{m}$ pore size nitrocellulose membranes (Bio-Rad) in $1 \times$ Tris base/glycine/methanol blotting buffer, and immunoblotted with anti-PDGFR $\alpha$ (1:500, Santa Cruz Biotechnology, sc-338) antibody. All blots were first blocked for $1 \mathrm{~h}$ at room temperature (RT) in freshly prepared $3 \%$ nonfat dry milk in $1 \times$ TBS with $0.05 \%$ Tween 20 (TBST-MLK), incubated with the primary antibody overnight with agitation at $4^{\circ} \mathrm{C}$, washed in $1 \times \mathrm{TBS}$ with $0.05 \%$ Tween 20, and then incubated with the secondary antibody 1:3000 (horseradish peroxidase-conjugated goat anti-rabbit, Millipore;12-348) for $1 \mathrm{~h}$ with agitation at RT in TBST-MLK. After washes $(2 \times$ in TBST, $4 \times$ in $\mathrm{ddH}_{2} \mathrm{O}$ ), the immunoreactive bands were visualized using enhanced chemiluminescence (ECL-Prime, GE Healthcare) and captured by the Typhoon 9410 Variable Mode Imager (GE Healthcare). ECL signal intensities were quantified using the ImageQuant software (GE Healthcare). Optical densities were calculated for each band of interest after performing background correction (by subtracting the value of a band immediately above the band of interest in the same lane). The linear range for each antibody was determined using a 5 point dilution series of homogenate before running the experimental samples.

Translating ribosome affinity purification and RNA extraction. The protocol was essentially as described previously (Doyle et al., 2008; Heiman et al., 2008), with some modifications. Under anesthesia, S, SD, and W mice ( $n=6$ /group) were decapitated and the forebrain region was quickly dissected. Tissue was placed in $2 \mathrm{ml}$ of chilled lysis buffer $(20 \mathrm{~mm}$ HEPES KOH, 5 mм MgCl 2,150 mm KCl, 0.5 mм DTT, $100 \mu \mathrm{g} / \mathrm{ml}$ cycloheximide, protease inhibitors, $20 \mu \mathrm{l}$ Rnasin, $20 \mu \mathrm{l}$ Superasin) and homogenized with a Teflon-glass homogenizer. A postnuclear supernatant was prepared by centrifugation at $4^{\circ} \mathrm{C}$ for $10 \mathrm{~min}$ at $2000 \times \mathrm{g}$. NP-40 $(1 \%$ final) and DHPC ( $30 \mathrm{~mm}$ final) were added to the supernatant, mixed by gentle inversion, and incubated on ice for $5 \mathrm{~min}$. A postmitochondrial supernatant was prepared by centrifugation at $4^{\circ} \mathrm{C}$ for $10 \mathrm{~min}$ at $20,000 \times$ g. Antibody-bound beads were prepared by incubation of Streptavidin MyOne T1 Dynabeads (Invitrogen) with biotinylated Protein L (Fisher Pierce) for $35 \mathrm{~min}$ at RT in $1 \times$ PBS using gentle end-over-end rotation. Protein L-coated beads were collected on the DynaMag-2 magnet (Invitrogen) and washed $5 \times$ with $1 \times$ PBS containing $3 \%(w / v) ~ I g G$, Proteasefree BSA (Jackson ImmunoResearch Laboratories). Antibody binding was performed in $0.15 \mathrm{M} \mathrm{KCl}$ buffer (20 mM HEPES-KOH, $5 \mathrm{~mm} \mathrm{MgCl}_{2}$, $150 \mathrm{~mm} \mathrm{KCl}, 1 \% \mathrm{NP}-40,0.5 \mathrm{~mm}$ DTT, and $100 \mu \mathrm{g} / \mathrm{ml}$ cycloheximide) for $1 \mathrm{~h}$ at RT using gentle end-over-end rotation with $50 \mu \mathrm{g}$ each of two monoclonal anti-GFP antibodies (19C8 and 19F7, Memorial SloanKettering Cancer Center Monoclonal Antibody Core Facility). After antibody binding, beads were washed and resuspended in $0.15 \mathrm{M} \mathrm{KCl} \mathrm{buffer.}$ The postmitochondrial supernatant was combined with the GFP antibody-coated beads and incubated overnight with gentle end-overend rotation at $4^{\circ} \mathrm{C}$. Beads were then collected with the magnet and washed $4 \times$ in high-salt polysome wash buffer $(20 \mathrm{~mm}$ HEPES-KOH, 5 mм $\mathrm{MgCl}_{2}, 350 \mathrm{~mm} \mathrm{KCl}, 1 \% \mathrm{NP}-40,0.5 \mathrm{~mm}$ DTT, and $100 \mu \mathrm{g} / \mathrm{ml}$ cycloheximide). After washes, beads were collected, resuspended, and vortexed in $100 \mu$ l lysis buffer with $\beta$-mercaptoethanol from the Absolutely RNA Nanoprep kit (Agilent), and incubated for $10 \mathrm{~min}$ at RT. This RNA, which represents the mRNA immunoprecipitated from the targeted cell type (immunoprecipitated sample [IP] fraction), was then removed from the beads with the magnet and purified following the Nanoprep protocol, including on column DNase digestion. The RNA from the supernatant (unbound fraction [UB]) was isolated using the RNeasy Mini kit (QIAGEN). RNA levels in IP and UB samples were assessed by a Qubit Fluorometer (Invitrogen) with the Quant-iT RNA assay kit (Invitrogen, Q32852), and the quality of the RNA was assessed using the Agilent 2100 Bioanalyzer (Agilent).

Quantitative PCR. cDNA was synthesized from $7.5 \mathrm{ng}$ of RNA from each IP and UB sample isolated from each individual animal with SuperScript VILO cDNA synthesis kit (Invitrogen, 11754-050) and diluted fourfold. Real-Time PCR was performed using the ABI 7300 Real-Time PCR System (in triplicate) following the manufacturer's standard protocol, with SYBR Green PCR Master Mix (Applied Biosystems, 4309155) in a final volume of
$25 \mu$ l. Primers included the following: Gapdh forward 5'-CCAGAAGACT GTGGATGGC-3'; Gapdh reverse, 5'-TGAGCTTCCCGTTCAGCTC-3'; $M b p$ forward 5' - ATCCAAGTACCTGG CCACAG-3'; ${ }^{\prime} b p$ reverse $5^{\prime}$-CC TGTCACCGCTAAAGAAGC-3'; Gfap forward, 5' -GTAAAGACTGTGGA GATGCGGGATGGTGAGG-3'; Gfapreverse5'-GTGCTGGTGTGGGTGG GAACTGAG-3'; Syt1 forward 5'-GGCACTCACCATT TTTGGTT-3'; Syt1 reverse $5^{\prime}$-AGCTCCAGCAGAACATCTCG-3'; $P d g f r \alpha$ forward5' -ACCTTG CACAATAACGGGAG-3'; Pdgfr $\alpha$ reverse 5' -GAAGCCTTTCTCGTGGAC AG- $\left.3^{\prime}\right)$. Expression levels were calculated by the ddCT method via Applied Biosystems software, using Gapdh as the normalizing gene and UB samples as the calibrator.

Microarray: labeling, hybridization, and data analysis. For each IP and UB sample (6 IP and 6 UB for each of the three experimental groups, S, $\mathrm{SD}$, and $\mathrm{W}), 5 \mathrm{ng}$ of purified mRNA was amplified with the Ovation Pico WTA system (NuGen, \#3300). A total of $5 \mu \mathrm{g}$ of amplified material was then fragmented, biotin labeled with the Encore Biotin Module (Nugen, \#4200), hybridized to Affymetrix GeneChip Mouse Genome 4302.0 arrays ( $n=36$, one chip per mouse) following Affymetrix standard protocol, and scanned using the GC3000 7G scanner (Affymetrix). Statistical analysis was performed using the Bioconductor Limma package (Smyth, 2004). For both IP and UB replicates, GeneChip Cel files were imported into Bioconductor, data were converted to $\log _{2}$ scale, and transcripts called "absent" in all chips were not used for analysis. Data were normalized within each behavioral state group using Robust Multiarray Average (Irizarry et al., 2003). To obtain a measure of the enrichment for each mRNA immunoprecipitated from the targeted cell type (IP) versus its expression in the tissue sample dissected for the analysis (UB), and to provide a list of enriched genes for the three behavioral states, IP and UB samples were compared using the Welch's $t$ test with Benjamini and Hochberg FDR multiple-test correction, and the IP/UB ratio was calculated: probe sets with IP/UB ratio $>2$ and $p<0.01$ were considered enriched, whereas probe sets with IP/UB ratio $<2$ and $p<0.01$ were considered depleted. Next, to independently verify the validity of the TRAP method, IP/UB ratios for 200 "top" genes previously found to be enriched in oligodendrocytes (Cahoy et al., 2008) were calculated (see Results). Finally, to identify transcripts that were differentially expressed across behavioral states ("sleep" and "wake" genes, whether or not enriched in oligodendrocytes), IP samples were compared using the Welch's $t$ test with Benjamini and Hochberg FDR multiple-test correction. All probe sets with fold change $>30 \%$ and $p<0.01$ were selected for further analysis (see Results). The lists of sleep and wake genes were submitted to the DAVID (Database for Annotation, Visualization and Integrated Discovery) bioinformatics database for functional annotation (http://david.abcc.ncifcrf.gov/) (Huang da et al., 2009). The background list used in the program included all the genes assigned to Affymetrix GeneChip Mouse Genome 4302.0 arrays. The enrichment score was determined through DAVID and represents the geometric mean (in $-\log$ scale) of member's modified Fisher Exact $p$ values associated with each annotation term inside each cluster. The gene ontology terms were gathered based on the known annotation of the submitted genes with respect to biological process. In subsequent analyses, lists of genes known to be specific for OPCs, preoligodendrocytes, and mature oligodendrocytes (Cahoy et al., 2008) were also used as background. Array raw data and expression data are available at NCBI GEO database (GSE48369).

$B r d U$ studies. To determine whether sleep affects OPC proliferation, mice were given an intraperitoneal injection of BrdU (300 $\mu \mathrm{g} / \mathrm{g}$ body weight, dissolved in saline) at 8 P.M. (W group, $n=6$ ), at 8:00 A.M. (S and SD groups, $n=6$ group). In a follow-up experiment, to determine the effects of specific sleep stages on OPC proliferation, 10 additional mice were implanted with EEG electrodes as described above, except that frontal and parietal screws were simply apposed on top of the skull after partial skull thinning; drilling was intermittent and a cold sterile solution was periodically applied to the skull to reduce heat-induce cortical damage. This was done to minimize the risk of cortical inflammation, which can influence subsequent cell counting. All animals were killed after $\sim 8 \mathrm{~h}$ from the injection to ensure that they were exposed to BrdU for a comparable amount of time. After perfusion (see above), brains were removed, postfixed overnight in the same fixative, and cut on a Vibratome in $40 \mu \mathrm{m}$ coronal sections, which were collected in PB in serial groups of 

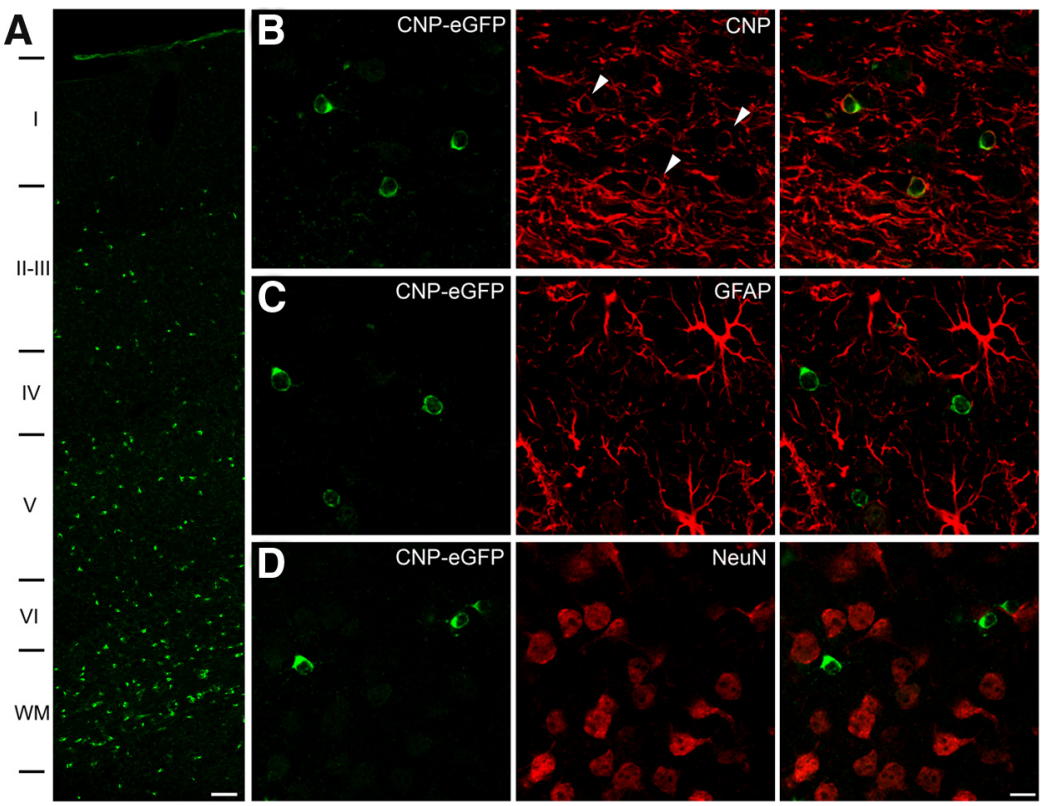

Figure 1. CNP-eGFP expression is specific for oligodendrocytes. $A$, CNP-eGFP $^{+}$cell distribution in frontal cortex and white matter (WM). Roman numerals indicate cortical layers. Scale bar, $45 \mu \mathrm{m}$. B, Double-labeling studies showing colocalization (arrows) of CNP-eGFP (green) and the oligodendrocyte marker CNP (red). C, D, Double-labeling studies showing the absence of colocalization between CNP-eGFP (green) and the astrocytic marker GFAP (red) or the neuronal marker NeuN (red). B-D, Scale bar, $15 \mu \mathrm{m}$.

5 and then used for immunocytochemistry. Frontal cortex sections $(n=$ $3 /$ mouse) were pretreated with $\mathrm{HCl} 2 \mathrm{~N}$ at $37^{\circ} \mathrm{C}$ for $30 \mathrm{~min}$, washed $3 \times$ in $\mathrm{PB}, \mathrm{pH} 7.4$, rinsed in a blocking solution (NGS 5\%, 0.1\% Triton X-100) for $1 \mathrm{~h}$, and then incubated overnight $\left(4^{\circ} \mathrm{C}\right)$ in the same blocking solution containing a mixture of anti-PDGFR $\alpha$ (1:500, Santa Cruz Biotechnology; sc-338) and anti-BrdU (1:1000, Serotec; OBT0030G). All sections were then exposed for $1.5 \mathrm{~h}$ to a solution (NGS 5\%, 0.1\% Triton X-100) containing a mixture of AlexaFluor-568 (1:250) and AlexaFluor-488 (1: 250) conjugated secondary antibodies. Sections were washed and examined with a confocal microscope. Control experiments were performed as above. The entire frontal cortex was viewed under a Lump Plan Fl $\times 20$ objective (numerical aperture 0.95 ) and nuclei that had incorporated BrdU were counted $\left(\mathrm{BrdU}^{+}\right)$. Only nuclei displaying a uniform staining were counted and pial-positive cells were not included in the analysis. Every $\mathrm{BrdU}^{+}$cell was also scored for $\operatorname{PDGFR} \alpha$ expression. All $\mathrm{BrdU}^{+} /$ PDGFRF $\alpha^{+}$cells were counted. Image processing and cell counting were performed on ImageJ and Photoshop CS2 (Adobe Systems). For the EEG group, staging and EEG data analysis were done as described above.

\section{Results}

To confirm the specific expression of CNP in oligodendrocytes, the brains of three adult heterozygous CNP-eGFP-L10a BAC transgenic mice were processed for immunocytochemistry using antibodies against enhanced green fluorescent protein (eGFP), $\mathrm{CNP}$, a neuronal marker (anti-NeuN), and an astrocytic marker (anti-GFAP). eGFP ${ }^{+}$cells were widespread in all brain regions and more numerous in white matter than in gray matter (Fig. 1A). In line with published data (Cahoy et al., 2008; Doyle et al., 2008; Dougherty et al., 2010), eGFP staining was only present in $\mathrm{CNP}^{+}$cells, but not in $\mathrm{NeuN}^{+}$or $\mathrm{GFAP}^{+}$cells (Fig. $1 B-D$ ). To ensure consistency during dissection of the brain samples, and to include fiber-rich areas, TRAP microarray studies were performed on the entire forebrain region.

Sleep/wake pattern and response to sleep deprivation in CNPeGFP-L10a mice

Before assessing the effects of sleep and wake on oligodendrocyte gene expression, we tested whether CNP-eGFP-L10a mice show a normal sleep/wake cycle. Five adult mice were implanted with chronic EEG electrodes and recorded continuously for several days in undisturbed conditions (baseline), as well as during and after sleep deprivation. Amount and daily distribution of NREM sleep, REM sleep, and wake were within the range published for most mouse lines (e.g., Franken et al., 1999; Huber et al., 2000; Vyazovskiy et al., 2004; Douglas et al., 2007). Specifically, CNPeGFP-L10a mice showed robust entrainment to the light-dark cycle, sleeping mainly during the light phase and staying awake most of the night, as expected for nocturnal animals. NREM sleep, characterized by large EEG slow waves (Fig. 2A), accounted for $34.4 \pm 1.4 \%$ of the $24 \mathrm{~h}$ cycle (Fig. $2 B ; 50.2 \pm 1.4 \%$ in $12 \mathrm{~h}$ light period). REM sleep, whose low voltage EEG pattern strongly resembles that of wake (Fig. 2A), occupied $5.9 \pm 0.3 \%$ of the $24 \mathrm{~h}$ cycle (Fig. $2 B ; 9.4 \pm 0.4 \%$ of the light period). As expected, NREM sleep was more abundant in the first part of the light phase relative to the second part, whereas an opposite trend was observed for REM sleep (Fig. 2B). Other sleep parameters, such as mean duration of NREM and REM episodes and number of brief arousals, were also within the normal range. EEG power spectra $(0.5-20 \mathrm{~Hz})$ showed the expected prominent peak of low frequencies during NREM sleep, and a peak in the $\theta$ frequency range (5-8 Hz) in REM sleep (Fig. 2C).

NREM slow-wave activity (SWA) is defined as the EEG power in the low-frequency range $(0.5-4 \mathrm{~Hz})$ during NREM sleep. In mammals and birds, SWA is a reliable marker of sleep homeostasis, as it increases with time spent awake and declines in the course of sleep (Vyazovskiy et al., 2011). As expected, in CNPeGFP-L10a mice, SWA during baseline peaked at the beginning of the light phase, declined across the day, and was high again in the first hour of consolidated sleep at night, after the extended spontaneous wake period that typically occurs at the light/ dark transition (Fig. 2D, top). To further probe sleep regulation, mice were kept awake during the first $4 \mathrm{~h}$ of the light period and allowed to recover afterward. Sleep deprivation was successful: time spent in NREM sleep during deprivation was $<2 \%$ in all animals, and REM sleep never occurred. In the first $2 \mathrm{~h}$ after sleep deprivation, NREM sleep duration was significantly increased compared with baseline (Fig. 2E), whereas duration of REM sleep and total sleep did not change significantly (data not shown). SWA during the first hour of recovery sleep was increased relative to SWA at the beginning of the baseline light period in both frontal (Fig. 2D, bottom, F) and parietal cortex (data not shown). Overall, these results show that sleep patterns and mechanisms of sleep regulation in CNP-eGFP-L10a mice are normal.

\section{Quality controls for TRAP microarray data}

After confirming the successful purification of 18 S and 28 S rRNA from all CNP-eGFP-L10a mice (data not shown), we determined whether TRAP accurately enriched for oligodendrocyte-specific genes using two methods. First, in each oligodendrocyte, IP and $\mathrm{UB}$ from every mouse in the S, SD, and W group, we performed 
A
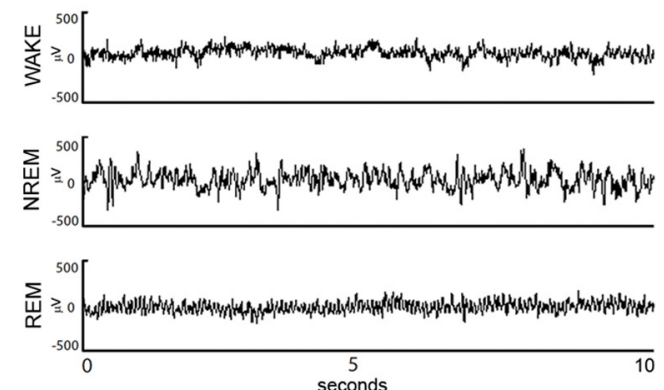

D
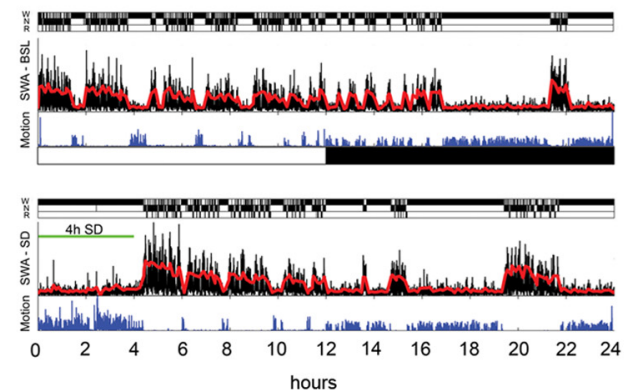

B

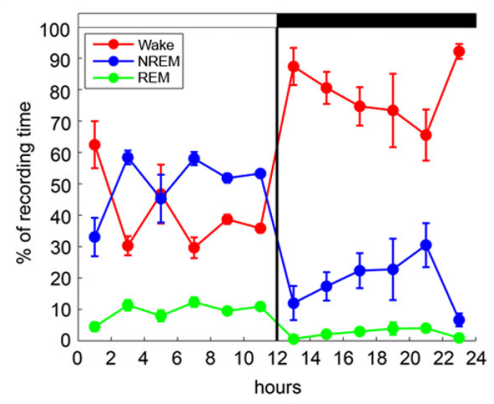

$E$

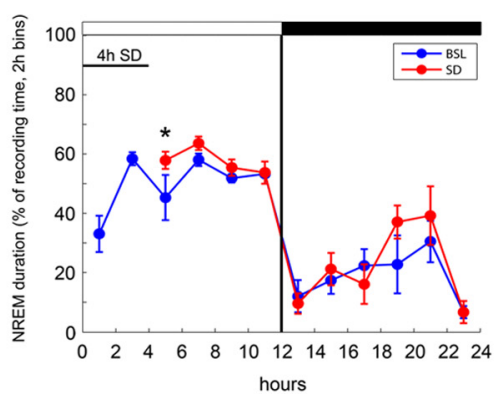

C

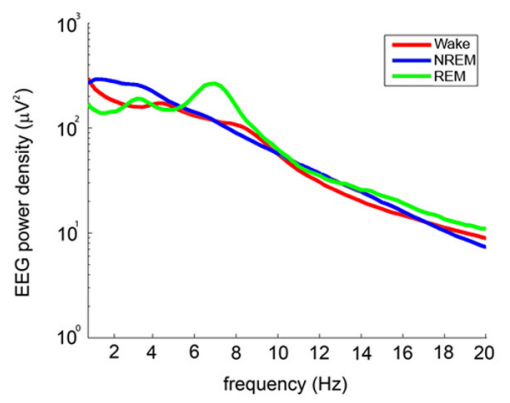

$\mathbf{F}$

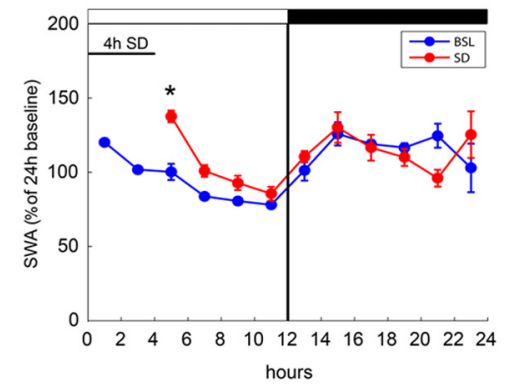

Figure 2. Sleep/wake pattern and response to sleep deprivation in CNP-eGFP-L10a mice. $A$, Representative EEG recordings (frontal cortex) of a CNP-eGFP-L10a mouse during wake, NREM sleep, and REM sleep. $\boldsymbol{B}$, Twenty-four hour sleep and wake patterns. In this and the next panels, white and black bars indicate the light and dark period, respectively. Values are mean \pm SEM. $\boldsymbol{C}$, Twenty-four hour wake, NREM sleep, and REM sleep EEG power density spectra $(0-20 \mathrm{~Hz})$ in CNP-eGFP-L10a mice $(0.25 \mathrm{~Hz}$ frequency bin). $\boldsymbol{D}$, Hypnogram, SWA time course, and motion activity in a representative CNP-eGFP-L10a mouse during baseline (BSL, top) and after $4 \mathrm{~h}$ of sleep deprivation (SD, bottom). $\boldsymbol{E}, \boldsymbol{F}$, Twenty-four hour time course of NREM duration and SWA for BSL and SD. ${ }^{*} p<0.05$, significant increase during the first $2 \mathrm{~h}$ of recovery sleep after SD relative to BSL (paired $t$ test).

qPCR for the genes coding for the oligodendrocyte marker MBP, the astrocytic marker GFAP, and the neuronal marker SYT1. In all animals, MBP expression was markedly higher in the IP sample relative to the UB sample, whereas the opposite was true for the other two markers $\left(F_{(2,15)}=96.03 ; p<0.0001\right)$. These changes were consistent across the three experimental groups $\left(F_{(2,15)}=0.21 ; p=0.27\right)$, suggesting that enrichment was comparable across S, SD, and $\mathrm{W}$ mice (Fig. $3 A$ ). Next, we examined the TRAP microarray data and calculated the IP/UB ratio for the 200 "top" genes previously identified as enriched in oligodendrocytes (positive controls), neurons (negative controls), or astrocytes (negative controls) (Cahoy et al., 2008). The great majority of probe sets for neuronal and astrocytic RNAs were enriched in all UB samples, whereas most oligodendrocyte-specific RNAs were enriched in all IP samples (Fig. 3B, left column). Thus, TRAP consistently enriched for oligodendrocyte-specific genes in all our samples.

Although CNP is broadly considered a marker of mature oligodendrocytes, it is also expressed at much lower levels in earlier stages of oligodendrocyte maturation (Yu et al., 1994; Belachew et al., 2003; Dawson et al., 2003; Aguirre et al., 2004; Jackson et al., 2006). Thus, we also calculated separately the IP/UB ratio for the top 500 genes previously identified as specific for OPCs, premyelinating oligodendrocytes, and mature oligodendrocytes (Cahoy et al., 2008). The great majority of the probe sets specific for OPC mRNAs resulted enriched in all UB samples relative to all IP samples, whereas the opposite was true for the genes specific for mature oligodendrocytes, most of which were enriched in the IP samples (Fig. 3B). By contrast, approximately half of the top 500 genes specific for premyelinating oligodendrocytes were enriched in the IP samples (Fig. 3B). Thus, these experiments showed that, as expected based on the known pattern of expression of CNP, our IP samples were not strictly specific for mature oligodendrocytes but contained a detectable amount of mRNAs belonging to cells of the same lineage but at an earlier stage of development. To confirm these results, we assessed the percentage of colocalization of the $\mathrm{eGFP}^{+}$cells with PDGFR $\alpha$, a marker of OPCs, O4, a marker of preoligodendrocytes, and CNP (Dawson et al., 2003; Nishiyama et al., 2009). We found that $2.9 \pm 0.47 \%$ of $\mathrm{eGFP}^{+}$ cells were OPCs, $12.17 \pm 1.24 \%$ were $\mathrm{O}^{+}$cells, and $80.24 \pm$ $11.22 \%$ were mature oligodendrocytes (Fig. $3 C$ ), confirming that the expression of eGFP is mostly, but not exclusively, confined to mature oligodendrocytes.

Next, because the cellular composition of the extracted pool was not homogeneous and could differ across our samples, we performed qPCR for the OPC marker Pdgfr $\alpha$ in each IP sample and UB sample from every S, SD, and $\mathrm{W}$ mouse. In all animals, $P d g f r \alpha$ expression was higher in the UB sample relative to the IP sample, and consistently so across all behavioral states $\left(F_{(2,15)}=\right.$ $0.15 ; p=0.87$; Fig. $3 D$ ). We also looked at the expression of $C n p$ as assessed by the 3 probe sets for Cnp present in the microarrays and found that among the IP samples none showed significant changes across the three experimental groups (average $\log _{2}$ intensity values of 3 probe sets: $S=14.2 \pm 0.06, \mathrm{~W}=14.1 \pm 0.12$, $\mathrm{SD}=14.2 \pm 0.04)$. Finally, we counted the number of eGFP ${ }^{+}$ cells that expressed PDGFR $\alpha$ or CNP in a separate group of $S$ and $\mathrm{SD}$ mice not used for the microarray study ( $n=3$ mice/group). Quantitative analysis showed no significant differences between experimental groups (PDGFR $\alpha, \mathrm{S}=2.8 \pm 0.34 \%, \mathrm{SD}=2.77 \pm$ $0.23 \%$; CNP, $\mathrm{S}=84.2 \pm 10.46 \%$, SD $=85.1 \pm 2.87 \%$; Fig. $3 E$ ). Thus, we conclude that the relative proportion of OPCs and mature oligodendrocytes does not differ within the $\mathrm{eGFP}^{+}$population used in our microarray experiments. 
A

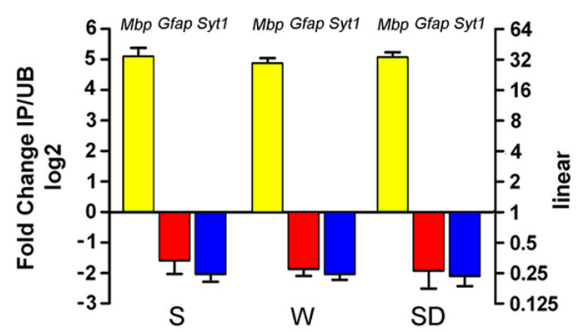

B Astrocytic/Neuronal/OL
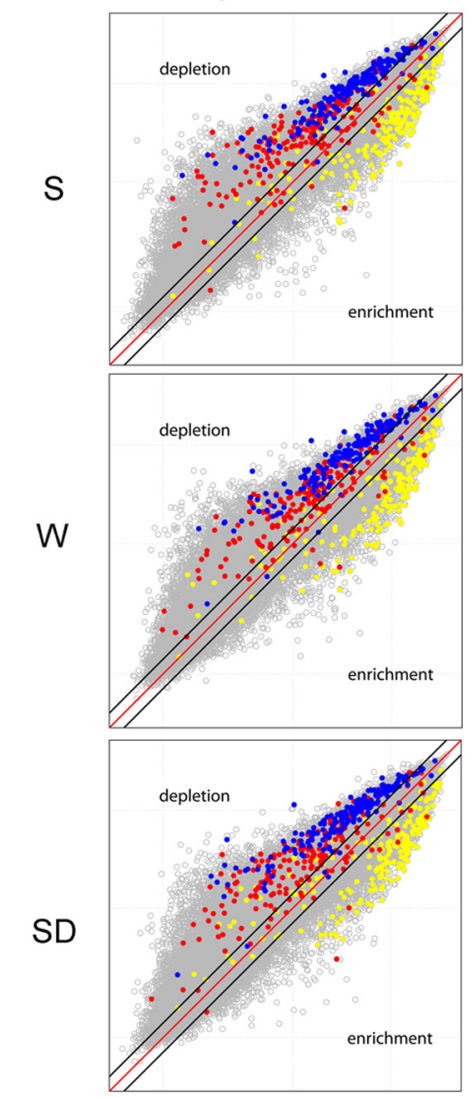

C

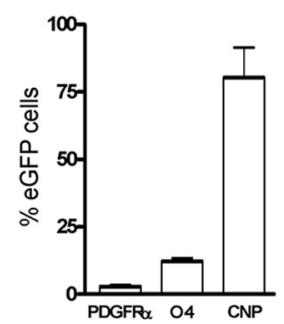

OPCs
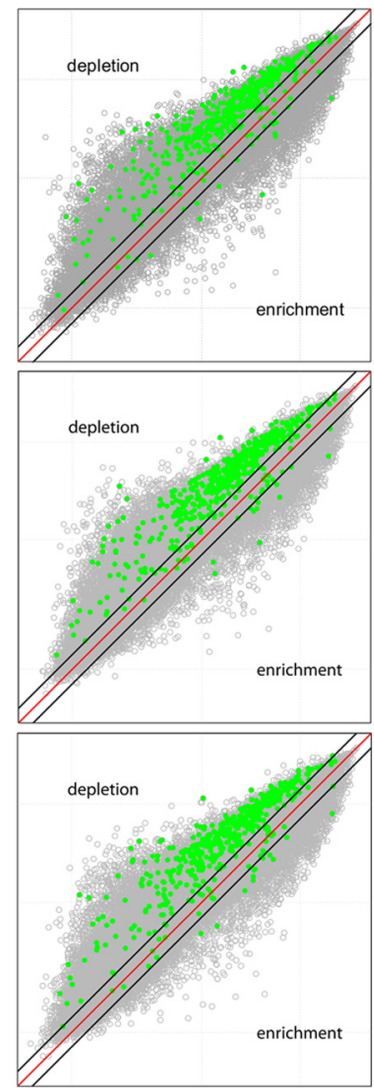

D

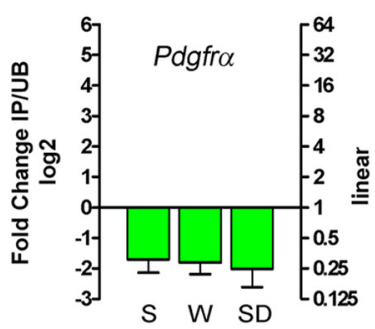

preOLs
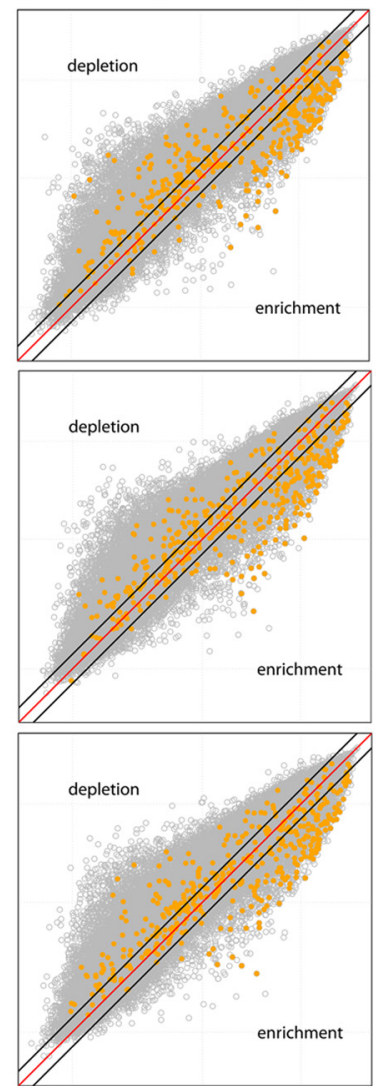

E

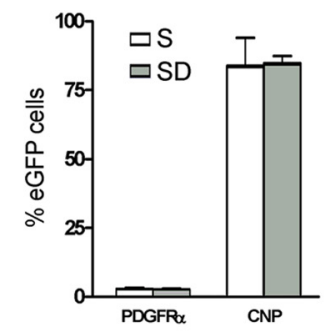

Figure 3. Enrichment analysis of CNP-eGFP-L10a IP samples. $A$, qPCR expression (mean $\pm S D, n=18,6$ per group) of the cell-specific marker for oligodendrocytes (Mbp) is consistently enriched in the IP RNA across all groups (W, S, and SD), whereas the negative controls (Gfap for astrocytes, Syt 1 for neurons) are consistently enriched in the UB samples. $\boldsymbol{B}$, Scatter plots show normalized mean expression values for IP ( $x$-axis, $n=18,6$ per group) and UB ( $y$-axis, $n=18,6$ per group) samples of $S, W$, and SD groups. The middle diagonal red line indicates equal expression, and the black lines to each side indicate one log-fold enrichment or depletion. Left column, in all three experimental groups, the top 200 genes identified by Cahoy et al. (2008) as specific for mature oligodendrocytes (yellow) are enriched in IP samples, whereas the top 200 genes specific for astrocytes (red) and neurons (blue) are enriched in S, W, and SD UB samples. The remaining columns show enrichment based on the top 500 genes identified by Cahoy et al. (2008) as specific for OPCs (green), premyelinating oligodendrocytes (orange, pre0Ls), and mature oligodendrocytes (yellow, OLs). C, Histogram shows the percentage (mean \pm SD) of eGFP ${ }^{+}$cells that colocalize with PDGFR $\alpha, 04$, and CNP. D, qPCR expression (mean \pm SD, $n=18,6$ per group) of the OPC marker Pdgfr $\alpha$ is consistently enriched in the UB RNA across all groups (W, $S$, and SD). $E$, Histogram shows the percentage (mean \pm SD) of eGFP ${ }^{+}$cells that colocalize with PDGFR $\alpha$ and CNP in $S(n=3)$ and SD mice $(n=3)$.

\section{Oligodendrocyte genes affected by sleep and wake}

To identify the specific effects of behavioral state on oligodendrocyte gene expression, we compared oligodendrocyte immunoprecipitated samples (IP, 18 total) from all three experimental groups (S, W, and SD, 6/group). All analyses were run on the probe sets that were called "present" in at least one sample, which represented $\sim 73 \%$ of all probe sets $(33,128$ of 45,101$)$, whether or not they were enriched in IP samples relative to UB samples (see Materials and Methods). This is because our goal was to identify all sleep/wake-dependent genes expressed in oligodendrocytes, independent of whether they were over-represented in this cell type relative to neurons or astrocytes. Using a false dis- covery rate of $1 \%$, we found that 359 probe sets, representing 357 unique genes, were differentially expressed because of time of day (3:00 A.M. vs 3:00 P.M.). Thus, the levels of $2.1 \%$ of all genes expressed in oligodendrocytes changed because of circadian factors, independent of behavioral state, given that IP samples collected at 3:00 A.M. came from spontaneously awake mice, whereas samples collected at 3:00 P.M. came from both sleeping and sleep-deprived animals. Conversely, 743 probe sets, representing 714 unique genes $(2.1 \%)$, changed their expression because of the sleep/wake cycle independent of time of day. As in previous work (Cirelli et al., 2004), "sleep" genes were defined as those expressed at higher levels in the sleep group (6-7 h of sleep) 
relative to both wake groups (6-7 h of spontaneous wake, $4 \mathrm{~h}$ of sleep deprivation), whereas "wake" genes were those with higher expression in both spontaneous and forced wake than in sleep. Because spontaneously awake mice were collected during the dark period while sleep-deprived mice were kept awake in the first part of the light phase, sleep and wake genes as defined here reflect changes resulting from behavioral state, without confounding effects resulting from time of day or exposure to light. Moreover, because to be defined as "wake" a gene needed to be higher in both spontaneously awake and sleep-deprived animals, confounding effects resulting from the sleep deprivation procedure, including stress, were controlled for. We identified 310 sleep genes (0.9\%) and 404 wake genes (1.2\%), and an extensive analysis of the literature suggested that they belonged to distinct categories. To confirm this, a statistical approach using gene annotation enrichment analysis (DAVID) was performed to elucidate the biological processes associated with sleep and wake. To assess the extent to which a given gene set is over-represented in a gene population background, we used the group enrichment score, which is calculated through DAVID and ranks the significance of each annotation cluster based on relatedness of the annotation terms and the genes associated with them (Fig. 4A). We found that in sleep there was an over-representation of genes that are involved in lipid metabolism, including phospholipid synthesis and myelination (Dgat2, Cds1, Elovl7, Chka, Opalin, Qk, and Pllp), are associated with axon repulsive guidance (Sema4b, Sema6a, Tmod1, and Slitrk6), and promote cell proliferation (Yap1, Nrg2, Rbn3, Mxd3, and Hydin). The functional categories enriched during wake, instead, included those involved in apoptosis and cellular stress response (Acin1, Bcat1, Otud7b, Nr4a1, Hip1, HSPE1, HSP90aa1, Irf8, and Traf6), as well as in cell differentiation and development (Creb1, YY1, Hipk1, Bambi, Gli2, Msi2, Sox17, and Fgf1).

Next, we performed three additional, more focused, clustering analyses, one for each of the three lists of genes preferentially expressed in OPCs, premyelinating oligodendrocytes, and mature oligodendrocytes (Cahoy et al., 2008). As expected, a comparison of the functional gene categories across cell types showed that many OPCs genes are involved in cell development, whereas many genes expressed at later stages of maturation are involved in lipid synthesis, cell signaling, and cytoskeleton modifications. Importantly, among the functional categories of OPC-enriched genes, those associated with developmental processes, including cell proliferation and growth, were over-represented in sleep, whereas those associated with cellular stress, metabolism, and cell differentiation were over-represented in wake (Fig. 4B). At later developmental stages (premyelinating oligodendrocytes and oligodendrocytes), genes associated with lipid metabolism were over-represented in sleep, whereas genes involved in apoptosis, cell differentiation, and cytoskeleton were over-represented in wake (Fig. 4B).

\section{Effect of sleep and wake on the proliferation rate of OPCs}

The microarray results suggested that at all developmental stages wake genes are preferentially involved in the cellular stress response and cell differentiation, whereas many sleep genes are involved in cell proliferation in immature oligodendrocytes, and in lipid metabolism in more mature cells. We therefore asked whether the number of OPCs and their turnover might be affected by behavioral state. To assess the rate of OPC proliferation across the sleep/wake cycle, we collected three additional groups of mice according to sleep/wake criteria similar to those used for the microarray study ( $~ 8 \mathrm{~h}$ of S, SD, or W; $n=6$ /group). Mice were injected with BrdU, a synthetic nucleoside that is incorporated into the newly synthesized DNA of replicating cells. BrdU was injected at the beginning of the light period in the S and SD groups and at the beginning of the dark period in the $\mathrm{W}$ group. All mice were killed $\sim 8 \mathrm{~h}$ after the injection after having spent most of the time either asleep or awake (S $8.8 \pm 0.8 \mathrm{~h}, \mathrm{~W} 8.1 \pm$ $\left.0.5 \mathrm{~h}, \mathrm{SD} 8.4 \pm 0.8 \mathrm{~h}, F_{(2,15)}=2, p=0.2\right)$, to ensure equal exposure to BrdU in all animals. Quantitative analysis of BrdU staining showed a larger number of $\mathrm{BrdU}^{+} / \mathrm{PDGFR} \alpha^{+}$cells in $\mathrm{S}$ $\left(3.28 \pm 0.73\right.$ cells $/ \mathrm{mm}^{2}$, one-way ANOVA: $F_{(2,15)}=16.8, p<$ $0.0001)$ compared with both $\mathrm{W}\left(1.68 \pm 0.35\right.$ cells $/ \mathrm{mm}^{2}, p<$ $0.001)$ and SD $\left(1.76 \pm 0.46\right.$ cells $/ \mathrm{mm}^{2}, p<0.001$; Fig. $\left.5 A\right)$. Because the number of $\mathrm{BrdU}^{+} / \operatorname{PDGFR} \alpha^{+}$cells after sleep was increased to a similar extent relative to both spontaneous wake at night and forced wake during the day, possible confounding effects resulting from circadian time and/or stress related to sleep deprivation could be ruled out.

Using another approach to assess the effects of sleep and wake on OPC proliferation, we measured the number of closely apposed pairs of cells or "doublets" in the frontal cortex of four additional experimental groups (6 mice/group), including three groups collected according to the sleep/wake criteria used for the BrdU study ( $\sim 6-7 \mathrm{~h}$ of S, SD, or W), as well as a fourth group of mice collected after $6 \mathrm{~h}$ of recovery sleep after $6 \mathrm{~h}$ of sleep deprivation (RS). "Doublets" (Fig. $5 B$, example in the small frame) likely represent cells in division (Mallon et al., 2002). Thus, we estimated the number of PDGFR $\alpha^{+}$cells forming a doublet in the four experimental groups. We found that the occurrence of doublets differed depending on behavioral state $\left(F_{(3,23)}=14.24\right.$; $p<0.0001 ; \mathrm{S} 6.5 \pm 1.4$ cells $/ \mathrm{mm}^{2} ; \mathrm{SD} 2.2 \pm 1.1 \mathrm{cells} / \mathrm{mm}^{2} ; \mathrm{W}$ $4.1 \pm 1.4$ cells $/ \mathrm{mm}^{2}$; RS $9.7 \pm 3.1$ cells $/ \mathrm{mm}^{2}$; Fig. $\left.5 B\right)$. In general, mice that had been asleep ( $\mathrm{S}$ and $\mathrm{RS}$ groups) showed an increased number of doublets relative to mice that spent a similar amount of time spontaneously awake (RS vs W, $p<0.01$ ) or were sleepdeprived ( $\mathrm{S}$ vs SD, $p<0.01$; RS vs SD, $p<0.001$ ). Of note, the highest number of doublets was observed in the RS group, suggesting a rebound of OPC proliferation after sleep deprivation (Fig. 5B).

Finally, given the possible promoting role of sleep in OPC proliferation, we then tested the relative impact of NREM and REM sleep in an additional group of 10 animals implanted for chronic EEG recordings. Mice were injected with BrdU at the beginning of the light period, and brains were collected $8 \mathrm{~h}$ later, after the animals spent on average $60 \pm 5.9 \%$ of time asleep (NREM, $51.3 \pm 5.3 \%$; REM, $8.7 \pm 1.3 \%$ ). Quantitative analysis of BrdU staining revealed that the number of $\mathrm{BrdU}^{+} / \mathrm{PDGFR} \alpha^{+}$ cells was positively correlated with the time spent in REM sleep $(r=0.79, p=0.007$; Fig. $5 C)$, and a positive, albeit not significant, trend was also found with total time spent asleep $(r=0.21)$. By contrast, no correlation was found between the number of $\mathrm{BrdU}^{+} / \mathrm{PDGFR} \alpha^{+}$cells and either the time spent in NREM sleep $(r=0.1)$, SWA $(r=-0.16)$, or SWE (slow-wave energy: SWA $\times$ time, $r=-0.1$ ) (data not shown).

These results show that OPC proliferation is higher after sleep than after a period without sleep. This difference could be due to the fact that cell proliferation is positively affected by sleep and/or is negatively impacted by the absence of sleep. In the second case, however, one would expect decreased OPC turnover after sleep deprivation, but similar turnover after sleep and spontaneous wake. We found, instead, that the rate of OPC proliferation was higher in sleep also relative to spontaneous wake, suggesting that sleep may have direct, positive effects on cell proliferation. 
A

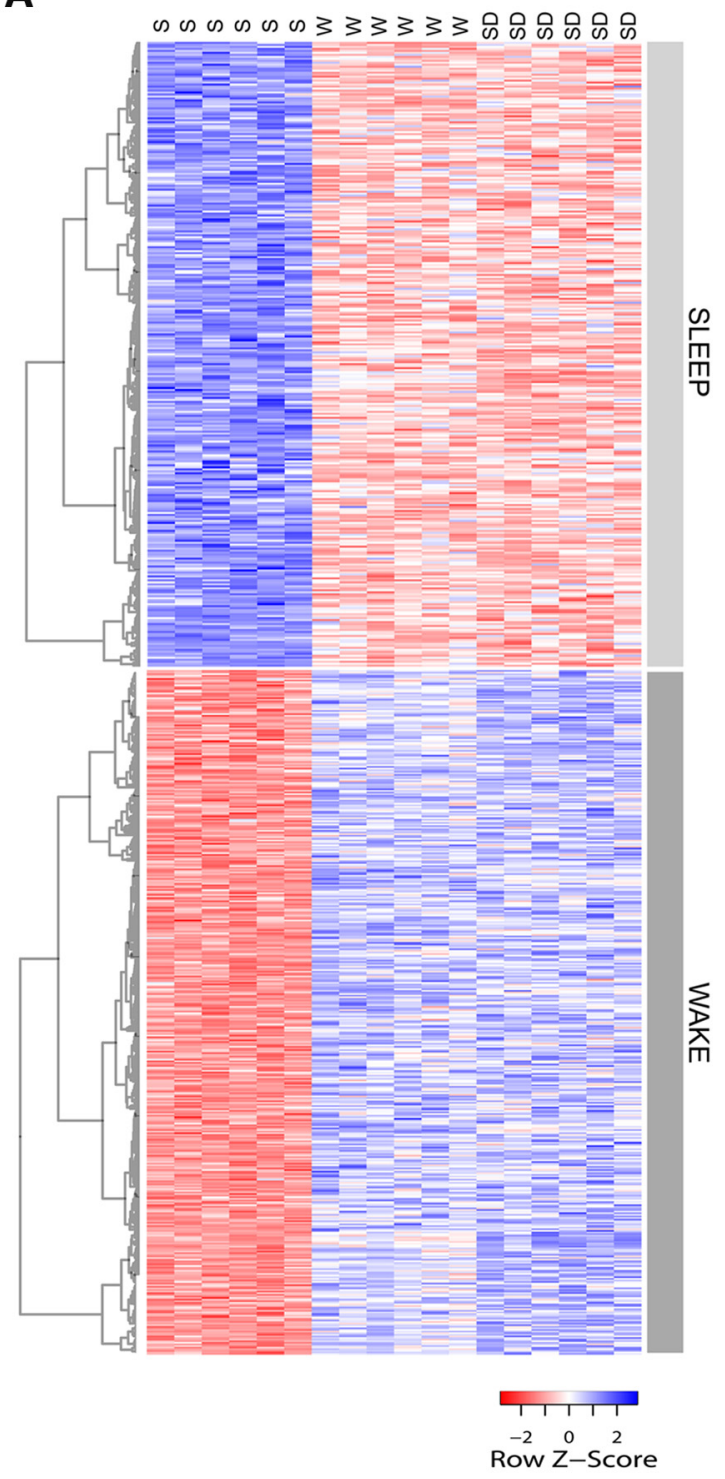

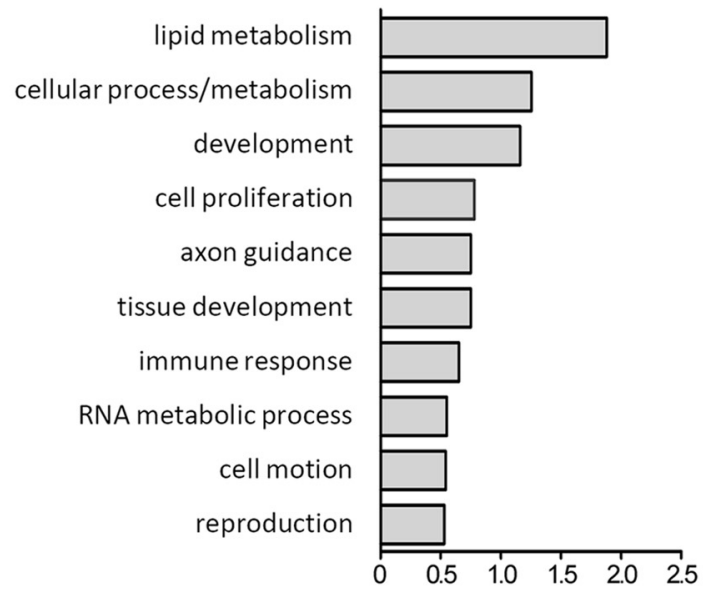

apoptosis development/cell differentiation

RNA metabolic process cellular process/metabolism negative regulation cell process tissue development fatty acid metabolism immuno response chromatin modification cytoskeleton

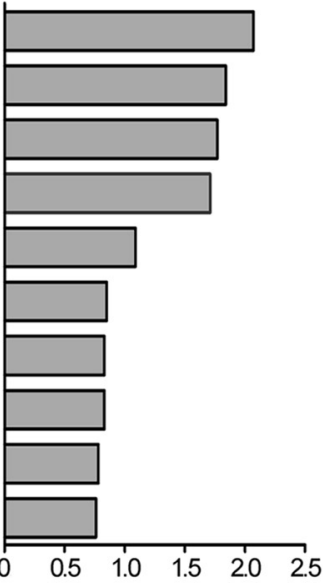

ENRICHMENT SCORE
B
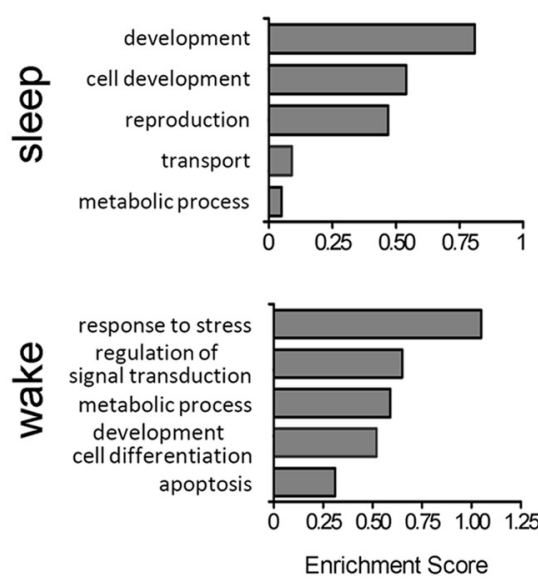

Relative to preOLs
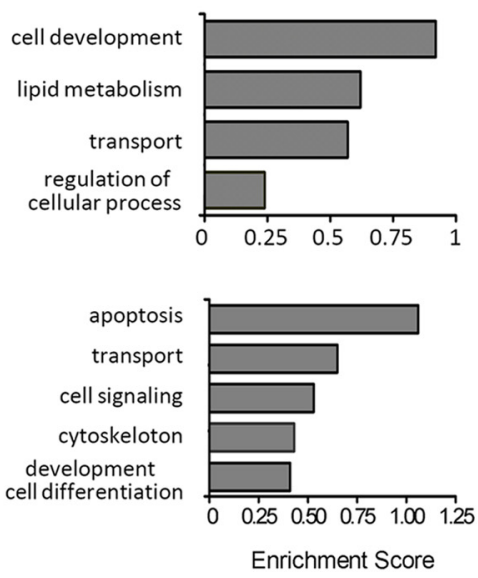

Relative to OLs
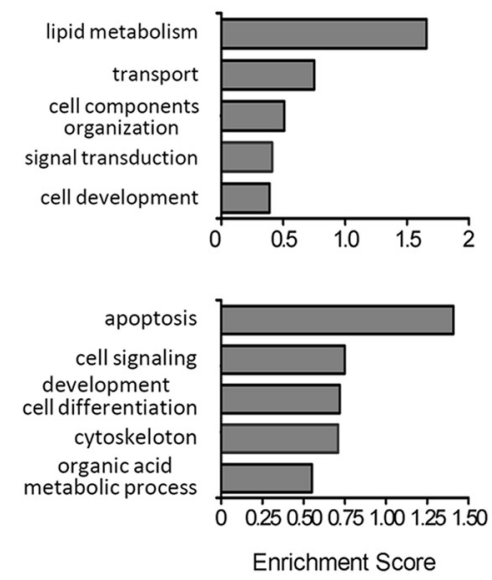

Figure 4. Functional characterization of genes differentially expressed in sleep $(S)$ and wake $(\mathrm{W}+\mathrm{SD})$. $\boldsymbol{A}$, Right, Heat diagrams show the probe set intensity for each individual animal in the three experimental groups. Left, A total of 286 genes for $S$ and 379 genes for W + SD were recognized and mapped for functional annotation analysis (DAVID default settings, except for final group $>$ 4 and multiple linkage threshold $=0.25$ ). Top 10 functional annotation clusters in order of enrichment score are shown for $S$ (top) and W $+S D$ (bottom). $B$, Functional characterization of genes regulated in S and W + SD relative to genes preferentially expressed in OPCs, premyelinating oligodendrocytes (preOLS), and mature oligodendrocytes (OLS) (DAVID default settings, except for multiple linkage threshold $=0.25$ ). Top 5 functional annotation clusters in order of enrichment score are shown for $S$ (top) and W + SD (bottom). 
A
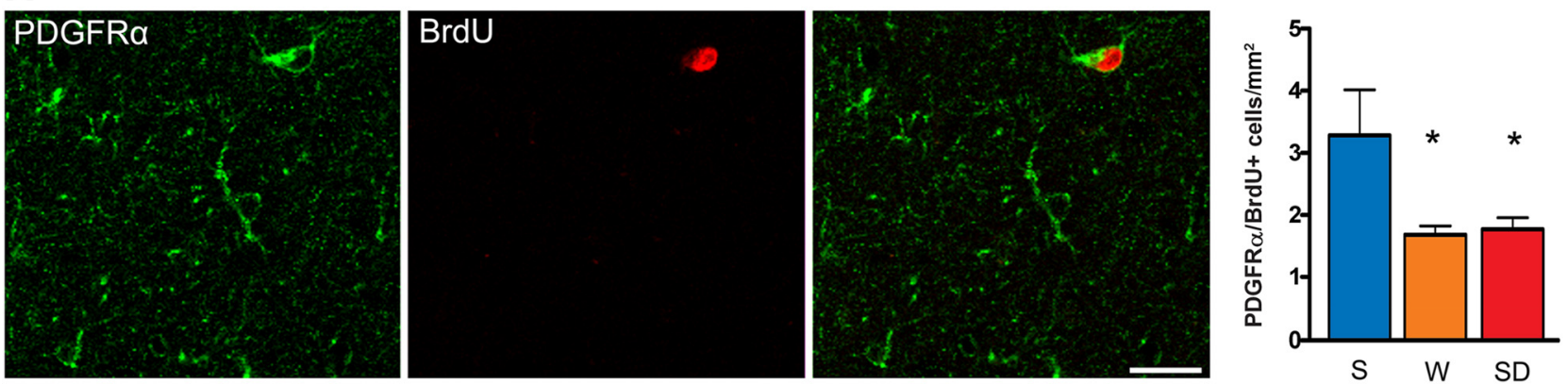

B
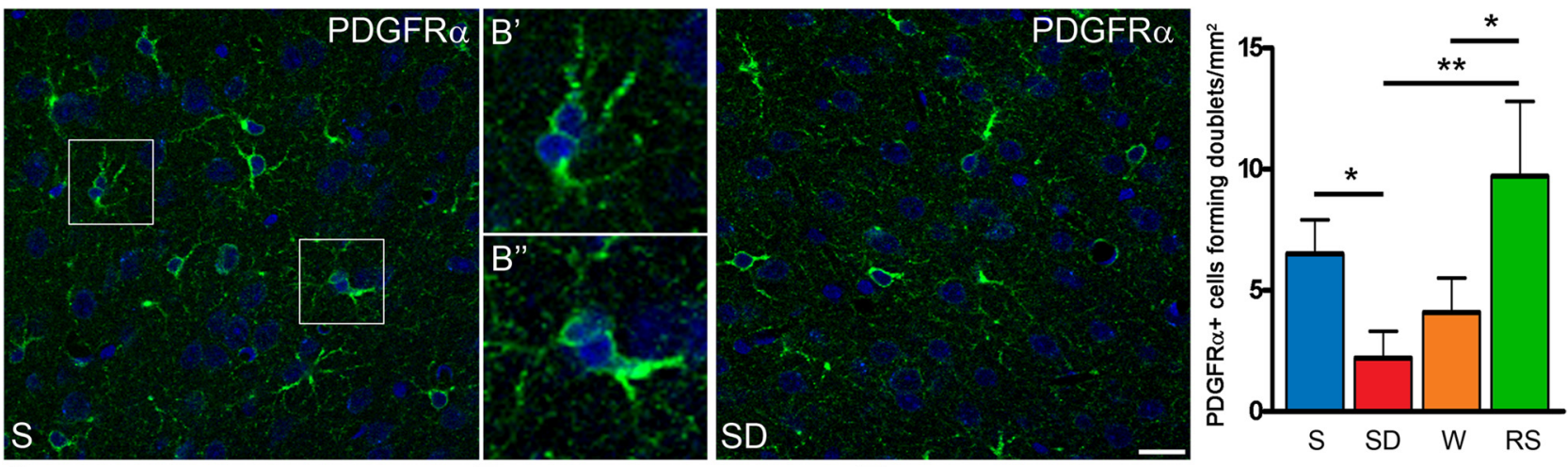

C

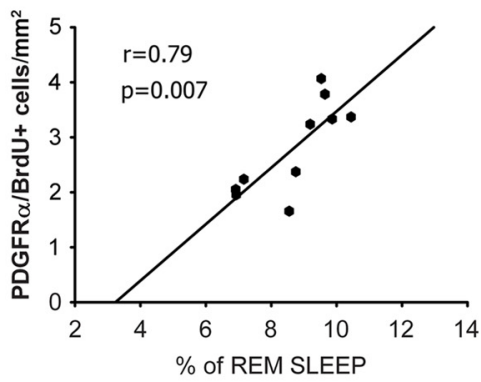

F

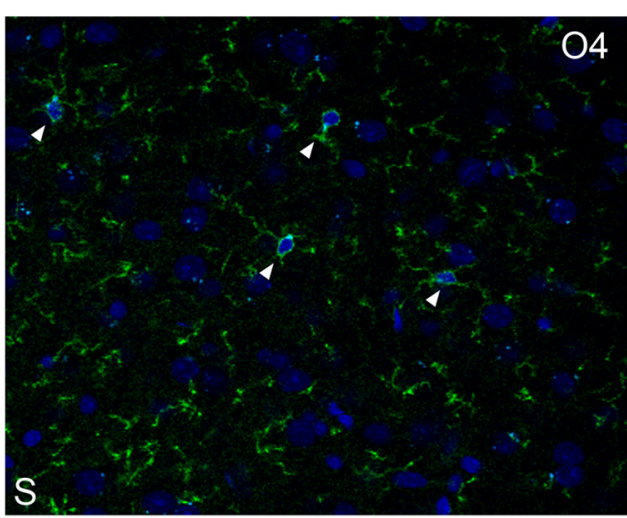

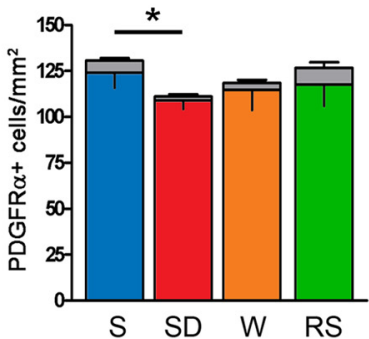

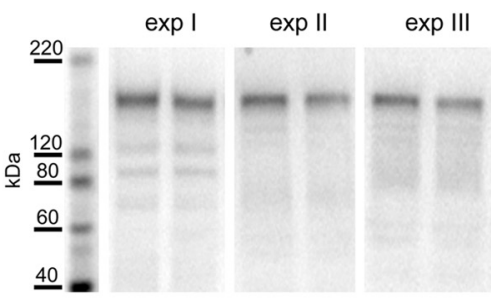

$S \quad S D \quad S \quad S D \quad S \quad S D$

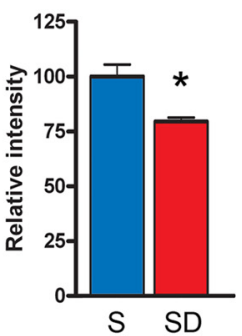

Figure 5. OPC proliferation and differentiation are affected by sleep and wake. $A$, Left, Double-labeling studies showing a colocalization of PDGFR $\alpha^{+}$cell (green) and a BrdU ${ }^{+}$cell in a representative microscopic field from a sleeping animal. Scale bar, $25 \mu \mathrm{m}$. Right, Number of PDGFR $\alpha^{+} / \mathrm{BrdU}^{+}$cells in $\mathrm{S}(n=6 \mathrm{mice}), \mathrm{W}(n=6)$, and SD $(n=6)$. Values are mean $\pm S D$. ${ }^{*} p<0.05$ (Tukey's post hoc test). $\boldsymbol{B}$, Left, Examples of PDGFR $\alpha^{+}$cells (green) in S and SD. The framed regions representing two examples of cell doublet are enlarged in $\boldsymbol{B}^{\prime}$ and $\boldsymbol{B}^{\prime \prime}$; cell nuclei were counterstained with propidium-iodide (blue). Scale bar, $20 \mu \mathrm{m}$. Right, PDGFR $\alpha^{+}$cells forming a doublet in frontal cortex of sleeping $(S, n=6)$, sleep-deprived (SD, $\left.n=6\right)$, spontaneously awake (W, $n=6$ ), and recovering sleep after sleep deprivation (RS, $n=6$ ) mice. Values are mean $\pm S D .{ }^{*} p<0.01$ (Tukey'sposthoctest). ${ }^{* *} p<0.001$ (Tukey's posthoctest).C,Correlation of the number ofPDGFR $\alpha^{+} /$BrdU ${ }^{+}$cells with duration of REM sleep (rindicatesPearson coefficient). D, Quantitative analysis of PDGFR $\alpha^{+}$cells infrontal cortex of $S(n=6), \operatorname{SD}(n=6), \mathrm{W}(n=6)$, and RS $(n=6)$ mice. Values are mean \pm SD. ${ }^{*} p<0.05$ (Tukey's posthoctest). Cells forming a doublet are indicated in gray bars. $\boldsymbol{E}$, Western blotting results from three independent experiments (exp I-III), showing an increase of PDGFR $\alpha$ expression in Srelative to SD ( $n=12,4 \mathrm{~S}$, and 4 SD/experiment). Values are mean $\pm S D .{ }^{*} p<0.05$ ( $t$ test). $F$, Left, Examples of $04^{+}$cells (green) in S and SD; cell nuclei were counterstained with propidium-iodide (blue). Arrowheads indicate the cells scored as $04^{+}$. Scale bar, $20 \mu \mathrm{m}$. Right, Relative quantitative analysis of $04^{+}$cells in frontal cortex of $S(n=6)$ and SD $(n=5)$ mice. Values are mean \pm SD. ${ }^{*} p<0.05$ ( $t$ test). 


\section{Effect of sleep and wake on the number of OPCs}

We next measured whether sleep and wake affect not only the proliferation rate of OPCs but also their absolute number. Because PDGFR $\alpha$ is a reliable marker of OPCs (Dawson et al., 2003; Nishiyama et al., 2009), we counted the number of PDGFR $\alpha^{+}$ cells in the frontal cortex of mice from the same four experimental groups used for the doublet analysis (S, SD, W, RS). Statistical analysis highlighted a general effect of behavioral state $\left(F_{(3,23)}=\right.$ $4.36 ; p=0.016 ; \mathrm{S} 124.1 \pm 8.5 \mathrm{cells} / \mathrm{mm}^{2} ; \mathrm{SD} 108.8 \pm 4.8$ cells $/$ $\mathrm{mm}^{2}$; W $114.5 \pm 10.9$ cells $/ \mathrm{mm}^{2}$; RS $117.6 \pm 11.8$ cells $/ \mathrm{mm}^{2}$ ), and post hoc comparisons showed a significant increase of PDGFR $\alpha^{+}$cells in the S group relative to the SD group $(p<0.05$; Fig. $5 D$ ). The comparisons $\mathrm{S}$ versus $\mathrm{W}$ and RS versus $\mathrm{SD}$ also showed a trend in the same direction, although they did not reach significance (Fig. 5D). Again, because sleeping and sleepdeprived mice were collected at the same time of day, circadian factors cannot account for these findings.

We also measured the overall expression of PDGFR $\alpha$ in the entire forebrain after $6 \mathrm{~h}$ of sleep relative to $6 \mathrm{~h}$ of sleep deprivation. Western blot analysis on forebrain homogenates obtained from three independent experiments ( $4 \mathrm{~S}$ mice, $4 \mathrm{SD}$ mice/experiment) showed an increase of PDGFR $\alpha$ protein levels in S compared with SD $(20.5 \pm 5.6 \%, p=0.004$; Fig. $5 E)$, consistent with the higher number of PDGFR $\alpha^{+}$cells in the frontal cortex after several hours of sleep (Fig. 5D).

\section{Effects of sleep and wake on OPC differentiation}

Our results show that, on average, the number of OPCs is $\sim 10$ $15 \%$ higher when measured after several hours of sleep than after a similar time spent awake. Previous studies have reported that in the adult brain OPCs have a cell cycle time of 20-40 d (Psachoulia et al., 2009; Simon et al., 2011), and their overall number does not change (Dawson et al., 2003; Rivers et al., 2008; Psachoulia et al., 2009). Thus, one has to assume that, within the $24 \mathrm{~h}$ cycle, the "wave" of OPC proliferation that occurs during the major sleep phase (the day in mice), is followed either by cell death and/or by a "wave" of cell differentiation, which would normally occur during the major wake phase (the night in mice). Both these hypotheses would be consistent with our TRAP array data, which indicated that genes involved in apoptosis and cell differentiation are expressed at higher levels in premyelinating oligodendrocytes of awake mice. Previous experiments, however, found that OPCs undergo very little programmed cell death in the normal adult brain (Dawson et al., 2003). Moreover, another study that used the TUNEL and fluoro-Jade techniques to measure the number of apoptotic cells found very little, if any, evidence for cell death in any brain region even after prolonged (several days) sleep deprivation (Cirelli et al., 1999). Thus, although the focus of that study was not on glial cells, we reasoned that an increased rate of cell differentiation was more likely to account for the fact that OPC number may increase after a few hours of sleep (this study) and yet remain constant across days (Dawson et al., 2003; Rivers et al., 2008; Psachoulia et al., 2009). To test this hypothesis, we collected two additional groups of $\mathrm{S}(n=6)$ and $\mathrm{SD}(n=5)$ mice and counted the number of $\mathrm{O}^{+}$cells in frontal cortex. The phenotype marker $\mathrm{O} 4$ is a sulfatide preferentially expressed on the surface of preoligodendrocytes (Nishiyama et al., 2009; Girolamo et al., 2011). To simultaneously verify the effect of sleep and sleep loss on OPC density, we quantified the number of OPCs $/ \mathrm{mm}^{2}$ in the same sections. Quantitative analysis confirmed that OPC density was higher after sleep than after sleep deprivation (S $119.5 \pm 10.8$ cells $/ \mathrm{mm}^{2} ; \mathrm{SD} 103 \pm 11.2$ cells $/ \mathrm{mm}^{2}, p=0.036$, data not shown). By contrast, the number of $\mathrm{O}^{+}{ }^{+}$cells was sig- nificantly higher after sleep deprivation $\left(91.4 \pm 8.1 \mathrm{cells} / \mathrm{mm}^{2}\right)$ than after sleep $\left(79.1 \pm 5\right.$ cells $/ \mathrm{mm}^{2}, p=0.012$, Fig. $\left.5 F\right)$. The small number of OPCs coexpressing the marker $\mathrm{O} 4$ did not differ between S and SD (S $9.4 \pm 7.1$ cells $/ \mathrm{mm}^{2}$; SD $9 \pm 6$ cells $/ \mathrm{mm}^{2}$, $p=0.93$, data not shown). Overall, these results suggest that, although the total number of OPCs does not change in an adult brain, their turnover is affected by sleep and wake, such that OPCs proliferate preferentially during the light phase, which mice spend mostly asleep, and then tend to differentiate at night, when mice are awake.

\section{Discussion}

Hundreds of transcripts change their expression across behavioral states in rats, mice, sparrows, and flies (Cirelli and Tononi, 2000; Terao et al., 2003a, 2003b, 2006; Cirelli et al., 2004, 2005, 2006; Zimmerman et al., 2006; Conti et al., 2007; Mackiewicz et al., 2007; Maret et al., 2007; Jones et al., 2008; Seugnet et al., 2009; Winrow et al., 2009; Mongrain et al., 2010; Thompson et al., 2010; Vecsey et al., 2012). These transcriptomic studies have provided clues about sleep functions (Tononi and Cirelli, 2006; Mackiewicz et al., 2007; Maret et al., 2007), but until now sleep/ wake effects on specific cell types had remained unknown. Here we found that the expression of $>2 \%$ of all transcripts being translated in oligodendrocytes changes in relation to behavioral state, independent of time of day, light exposure, or stimulation resulting from the sleep deprivation procedure. Moreover, we found that sleep and wake favor different, often complementary, cellular functions in oligodendrocytes and that some of these functions vary depending on the oligodendrocyte developmental stage.

In both mature and premature oligodendrocytes, wake is associated with higher mRNA levels of genes involved in apoptosis and cellular stress response (Acin1, Bcat1, Otud7b, Nr4a1, Hip1, Irf8, Traf6, HSPE1, and HSP90aa1). Traf6 mediates apoptotic signal transduction from members of the TNF receptor superfamily (Geetha et al., 2005) and TNF $\alpha$ can cause toxicity and death of oligodendrocytes (Selmaj and Raine, 1988; Jurewicz et al., 2005). The induction of stress response and apoptotic genes during wake is most likely not unique to oligodendrocytes, as it was a consistent finding in previous transcriptomic studies. Oligodendrocytes, however, are among the metabolically most active cells in the brain, with high rates of synthetic activity required to produce and maintain vast amounts of myelin (RichterLandsberg, 2000), and may be especially vulnerable to cellular stress. Previous studies found no evidence of substantial cell death even after prolonged sleep deprivation (Cirelli et al., 1999), but the methods used, such as TUNEL staining, only detect the last phase of apoptosis, and the focus of those studies was on neurons. Future studies should test whether sleep loss may specifically impair myelin formation and/or maintenance.

Other wake genes regulate cell differentiation (Creb1, YY1, Hipk1, Bambi, Gli2, Msi2, Sox17, and Fgf1) and have been studied in OPCs. YY1 is an essential component of the transcriptional network regulating the transition of OPCs from cell cycle exit to differentiation (He et al., 2007), and high levels of Hipkl force progenitors cells residing within the subventricular zone to differentiate (Marinaro et al., 2012). Likewise, Sox 17, a transcription factor interacting with the wnt signaling, is increased during OPC differentiation and its inhibition arrests cell-cycle exit (Sohn et al., 2006).

In mature oligodendrocytes, sleep is mostly associated with higher expression of genes coding for phospholipid synthesis and myelination (Dgat2, Cds1, Elovl7, Chka, Opalin, Qk, and Pllp), 
confirming previous studies on whole cortical samples (Cirelli et al., 2004; Mongrain et al., 2010). The fact that several genes involved in phospholipid synthesis are preferentially transcribed in sleep is interesting in light of a recent study that used liquid and gas chromatography-mass spectrometry to measure changes in cortical metabolites between controls and sleep-deprived mice (Hinard et al., 2012). An unexpected, large increase in membrane breakdown of phospholipids was observed after sleep deprivation, suggesting that prolonged wake may negatively impact membrane phospholipids (Hinard et al., 2012).

In premature oligodendrocytes, on the other hand, sleep is associated with higher expression of genes promoting cell proliferation. Among these genes, Yap1 and Mxd3 interact with the Sonic hedgehog signaling pathway implicated in OPC migration and proliferation (Barisone et al., 2008; Fernandez et al., 2009), and $\mathrm{Nrg} 2$, similar to $\mathrm{Nrg1}$, interacts with the ErbB family of receptors, whose activation is essential for OPC proliferation (Canoll et al., 1996; Carraway et al., 1997; Du and Dreyfus, 2002).

The promoting role of sleep in OPC proliferation, suggested by microarray findings, was confirmed by counting the number of $\mathrm{BrdU}^{+} / \mathrm{PDGFR} \alpha^{+}$cells and PDGFR $\alpha^{+}$cells forming doublets. Similarly, the promoting role of wake in OPC differentiation, also suggested by microarray findings, was confirmed by counting the number of $\mathrm{O}^{+}$cells. OPCs are intriguing cells. They transform into myelinating oligodendrocytes during development and in the mature CNS (Rivers et al., 2008), where they are the main proliferating cell type and constitute $\sim 5 \%$ of all cells (Dawson et al., 2003). Because the overall number of OPCs in the adult brain does not change (Dawson et al., 2003; Rivers et al., 2008; Psachoulia et al., 2009), one could reasonably assume that the rates of OPC proliferation and differentiation are constant across the $24 \mathrm{~h}$ cycle and that the two processes are perfectly matched at any given circadian time. We show here, however, that this is not the case, at least in adult mice that tend to be asleep during the day and awake during the night.

Hippocampal neurogenesis declines during chronic sleep deprivation or sleep fragmentation (Guzmán-Marín et al., 2003, 2007; Meerlo et al., 2009). OPCs, therefore, are not the only dividing cells in the adult brain whose proliferation benefits from sleep, but they are certainly the largest group. Sleep deprivation still impairs hippocampal neurogenesis in adrenalectomized rats, and a stress-related elevation of glucocorticoids cannot fully account for the negative effects of sleep disruption (Meerlo et al., 2009). This result is consistent with our finding that, relative to sleep, OPC proliferation is reduced by half in both spontaneous and forced wake. Also consistent with our finding is the fact that the negative impact of sleep deprivation/disruption on hippocampal cell proliferation can be explained by a reduction in REM sleep, although a role for NREM fragmentation cannot be excluded (Meerlo et al., 2009). Of note, hippocampal neurogenesis declines mostly after chronic ( $>1 \mathrm{~d}$ ) sleep loss (Meerlo et al., 2009), whereas just a few hours of sleep deprivation negatively impacted OPC proliferation, suggesting that these cells may be especially sensitive to sleep loss.

Sleep is classically considered a time of restoration, and brain protein synthesis, as measured by leucine incorporation in rats and monkeys, increases during NREM sleep (Ramm and Smith, 1990; Nakanishi et al., 1997). It could be, therefore, that the positive effects of sleep on OPC proliferation and hippocampal neurogenesis reflect a generalized phenomenon whereby any cell actively dividing in the brain does so more during sleep than during wake. Recent evidence, however, suggests that this is not the case because adult-born granule cells in the mouse olfactory bulb are preferentially eliminated during sleep, and the rate of elimination is correlated with the amount of NREM sleep (Yokoyama et al., 2011).

In agreement with our results, a recent study showed that voluntary physical exercise inhibits OPC proliferation and enhances cell differentiation (Simon et al., 2011), suggesting that the different levels of motor activity associated with sleep and wake-all our mice had access to a running wheel—may account for at least some of the observed effects. At the cellular level, the mechanisms may be complex. OPCs in both gray and white matter can generate postsynaptic excitatory currents mediated by AMPA receptors (Bergles et al., 2000), and neuron-OPC synapses can undergo long-term potentiation (Lin and Bergles, 2004). These synapses are thought to regulate OPC proliferation, migration, and differentiation into oligodendrocytes (Mangin and Gallo, 2011). As discussed in the Introduction, glutamatergic transmission is higher in wake than in sleep and glutamate signaling inhibits OPC proliferation and promotes their differentiation (Gallo et al., 1996; Yuan et al., 1998; Cavaliere et al., 2012). Thus, glutamate signaling initiated by neurons is one of the possible mechanisms underlying the sleep/wake effects on OPCs. Other mechanisms are likely to play a role. Adenosine, whose extracellular levels increase during wake and decline during sleep (Porkka-Heiskanen and Kalinchuk, 2011), inhibits OPC proliferation and stimulates their differentiation (Stevens et al., 2002). Moreover, OPC proliferation and the ability to repair myelin damage increase in pregnant mice because of increased prolactin signaling (Gregg et al., 2007), consistent with the remission of multiple sclerosis during pregnancy. In humans, plasma prolactin levels are highest during sleep and lowest during wake (Linkowski et al., 1998). Of note, in young subjects prolactin is preferentially released during periods of high NREM slow-wave activity (Spiegel et al., 1995), whereas in older adults prolactin relase is positively correlated with REM sleep (Latta et al., 2005). In rodents sleep/wake changes in prolactin secretion are less characterized, but prolactin promotes REM sleep in animals (Obal et al., 2005). Together, overall lower levels of glutamate and adenosine and higher levels of prolactin may contribute to the positive effects of sleep on OPC proliferation and, ultimately, because mature oligodendrocytes must come from OPCs division (Richardson et al., 2011), on the formation and maintenance of myelin.

\section{Notes}

Supplemental material for this article is available at http://tononi. psychiatry.wisc.edu/pubs/ArrayOligoData.zip. This material has not been peer reviewed.

\section{References}

Aguirre AA, Chittajallu R, Belachew S, Gallo V (2004) NG2-expressing cells in the subventricular zone are type C-like cells and contribute to interneuron generation in the postnatal hippocampus. J Cell Biol 165:575-589. CrossRef Medline

Barisone GA, Yun JS, Díaz E (2008) From cerebellar proliferation to tumorigenesis: new insights into the role of Mad3. Cell Cycle 7:423-427. CrossRef Medline

Baumann N, Pham-Dinh D (2001) Biology of oligodendrocyte and myelin in the mammalian central nervous system. Physiol Rev 81:871-927. Medline

Belachew S, Chittajallu R, Aguirre AA, Yuan X, Kirby M, Anderson S, Gallo V (2003) Postnatal NG2 proteoglycan-expressing progenitor cells are intrinsically multipotent and generate functional neurons. J Cell Biol 161: 169-186. CrossRef Medline

Bergles DE, Roberts JD, Somogyi P, Jahr CE (2000) Glutamatergic synapses on oligodendrocyte precursor cells in the hippocampus. Nature 405:187191. CrossRef Medline

Bitton DA, Okoniewski MJ, Connolly Y, Miller CJ (2008) Exon level inte- 
gration of proteomics and microarray data. BMC Bioinformatics 9:118. CrossRef Medline

Cahoy JD, Emery B, Kaushal A, Foo LC, Zamanian JL, Christopherson KS, Xing Y, Lubischer JL, Krieg PA, Krupenko SA, Thompson WJ, Barres BA (2008) A transcriptome database for astrocytes, neurons, and oligodendrocytes: a new resource for understanding brain development and function. J Neurosci 28:264-278. CrossRef Medline

Canoll PD, Musacchio JM, Hardy R, Reynolds R, Marchionni MA, Salzer JL (1996) GGF/neuregulin is a neuronal signal that promotes the proliferation and survival and inhibits the differentiation of oligodendrocyte progenitors. Neuron 17:229-243. CrossRef Medline

Carraway KL 3rd, Weber JL, Unger MJ, Ledesma J, Yu N, Gassmann M, Lai C (1997) Neuregulin-2, a new ligand of ErbB3/ErbB4-receptor tyrosine kinases. Nature 387:512-516. CrossRef Medline

Cavaliere F, Urra O, Alberdi E, Matute C (2012) Oligodendrocyte differentiation from adult multipotent stem cells is modulated by glutamate. Cell Death Dis 3:e268. CrossRef Medline

Cirelli C (2009) The genetic and molecular regulation of sleep: from fruit flies to humans. Nat Rev Neurosci 10:549-560. CrossRef Medline

Cirelli C, Tononi G (2000) Gene expression in the brain across the sleepwaking cycle. Brain Res 885:303-321. CrossRef Medline

Cirelli C, Shaw PJ, Rechtschaffen A, Tononi G (1999) No evidence of brain cell degeneration after long-term sleep deprivation in rats. Brain Res 840: 184-193. CrossRef Medline

Cirelli C, Gutierrez CM, Tononi G (2004) Extensive and divergent effects of sleep and wakefulness on brain gene expression. Neuron 41:35-43. CrossRef Medline

Cirelli C, LaVaute TM, Tononi G (2005) Sleep and wakefulness modulate gene expression in Drosophila. J Neurochem 94:1411-1419. CrossRef Medline

Cirelli C, Faraguna U, Tononi G (2006) Changes in brain gene expression after long-term sleep deprivation. J Neurochem 98:1632-1645. CrossRef Medline

Cirelli C, Pfister-Genskow M, McCarthy D, Woodbury R, Tononi G (2009) Proteomic profiling of the rat cerebral cortex in sleep and waking. Arch Ital Biol 147:59-68. Medline

Conti B, Maier R, Barr AM, Morale MC, Lu X, Sanna PP, Bilbe G, Hoyer D, Bartfai T (2007) Region-specific transcriptional changes following the three antidepressant treatments electro convulsive therapy, sleep deprivation and fluoxetine. Mol Psychiatry 12:167-189. CrossRef Medline

Dash MB, Douglas CL, Vyazovskiy VV, Cirelli C, Tononi G (2009) Longterm homeostasis of extracellular glutamate in the rat cerebral cortex across sleep and waking states. J Neurosci 29:620-629. CrossRef Medline

Dawson MR, Polito A, Levine JM, Reynolds R (2003) NG2-expressing glial progenitor cells: an abundant and widespread population of cycling cells in the adult rat CNS. Mol Cell Neurosci 24:476-488. CrossRef Medline

Dougherty JD, Schmidt EF, Nakajima M, Heintz N (2010) Analytical approaches to RNA profiling data for the identification of genes enriched in specific cells. Nucleic Acids Res 38:4218-4230. CrossRef Medline

Douglas CL, Vyazovskiy V, Southard T, Chiu SY, Messing A, Tononi G, Cirelli C (2007) Sleep in Kcna2 knockout mice. BMC Biol 5:42. CrossRef Medline

Doyle JP, Dougherty JD, Heiman M, Schmidt EF, Stevens TR, Ma G, Bupp S, Shrestha P, Shah RD, Doughty ML, Gong S, Greengard P, Heintz N (2008) Application of a translational profiling approach for the comparative analysis of CNS cell types. Cell 135:749-762. CrossRef Medline

Du Y, Dreyfus CF (2002) Oligodendrocytes as providers of growth factors. J Neurosci Res 68:647-654. CrossRef Medline

Fernandez LA, Northcott PA, Dalton J, Fraga C, Ellison D, Angers S, Taylor MD, Kenney AM (2009) YAP1 is amplified and up-regulated in hedgehog-associated medulloblastomas and mediates Sonic hedgehogdriven neural precursor proliferation. Genes Dev 23:2729-2741. CrossRef Medline

Franken P, Malafosse A, Tafti M (1999) Genetic determinants of sleep regulation in inbred mice. Sleep 22:155-169. Medline

Gallo V, Zhou JM, McBain CJ, Wright P, Knutson PL, Armstrong RC (1996) Oligodendrocyte progenitor cell proliferation and lineage progression are regulated by glutamate receptor-mediated $\mathrm{K}^{+}$channel block. J Neurosci 16:2659-2670. Medline

Geetha T, Kenchappa RS, Wooten MW, Carter BD (2005) TRAF6mediated ubiquitination regulates nuclear translocation of NRIF, the p75 receptor interactor. EMBO J 24:3859-3868. CrossRef Medline
Girolamo F, Ferrara G, Strippoli M, Rizzi M, Errede M, Trojano M, Perris R, Roncali L, Svelto M, Mennini T, Virgintino D (2011) Cerebral cortex demyelination and oligodendrocyte precursor response to experimental autoimmune encephalomyelitis. Neurobiol Dis 43:678-689. CrossRef Medline

Gregg C, Shikar V, Larsen P, Mak G, Chojnacki A, Yong VW, Weiss S (2007) White matter plasticity and enhanced remyelination in the maternal CNS. J Neurosci 27:1812-1823. CrossRef Medline

Guzmán-Marín R, Suntsova N, Stewart DR, Gong H, Szymusiak R, McGinty D (2003) Sleep deprivation reduces proliferation of cells in the dentate gyrus of the hippocampus in rats. J Physiol 549:563-571. CrossRef Medline

Guzmán-Marín R, Bashir T, Suntsova N, Szymusiak R, McGinty D (2007) Hippocampal neurogenesis is reduced by sleep fragmentation in the adult rat. Neuroscience 148:325-333. CrossRef Medline

He Y, Dupree J, Wang J, Sandoval J, Li J, Liu H, Shi Y, Nave KA, CasacciaBonnefil P (2007) The transcription factor Yin Yang 1 is essential for oligodendrocyte progenitor differentiation. Neuron 55:217-230. CrossRef Medline

Heiman M, Schaefer A, Gong S, Peterson JD, Day M, Ramsey KE, SuárezFariñas M, Schwarz C, Stephan DA, Surmeier DJ, Greengard P, Heintz N (2008) A translational profiling approach for the molecular characterization of CNS cell types. Cell 135:738-748. CrossRef Medline

Hinard V, Mikhail C, Pradervand S, Curie T, Houtkooper RH, Auwerx J, Franken P, Tafti M (2012) Key electrophysiological, molecular, and metabolic signatures of sleep and wakefulness revealed in primary cortical cultures. J Neurosci 32:12506-12517. CrossRef Medline

Huang da W, Sherman BT, Lempicki RA (2009) Systematic and integrative analysis of large gene lists using DAVID bioinformatics resources. Nat Protoc 4:44-57. CrossRef Medline

Huber R, Deboer T, Tobler I (2000) Topography of EEG dynamics after sleep deprivation in mice. J Neurophysiol 84:1888-1893. Medline

Irizarry RA, Hobbs B, Collin F, Beazer-Barclay YD, Antonellis KJ, Scherf U, Speed TP (2003) Exploration, normalization, and summaries of high density oligonucleotide array probe level data. Biostatistics 4:249-264. CrossRef Medline

Jackson EL, Garcia-Verdugo JM, Gil-Perotin S, Roy M, Quinones-Hinojosa A, VandenBerg S, Alvarez-Buylla A (2006) PDGFR $\alpha$-positive B cells are neural stem cells in the adult SVZ that form glioma-like growths in response to increased PDGF signaling. Neuron 51:187-199. CrossRef Medline

Jones S, Pfister-Genskow M, Benca RM, Cirelli C (2008) Molecular correlates of sleep and wakefulness in the brain of the white-crowned sparrow. J Neurochem 105:46-62. CrossRef Medline

Jurewicz A, Matysiak M, Tybor K, Kilianek L, Raine CS, Selmaj K (2005) Tumour necrosis factor-induced death of adult human oligodendrocytes is mediated by apoptosis inducing factor. Brain 128:2675-2688. CrossRef Medline

Lanté F, Toledo-Salas JC, Ondrejcak T, Rowan MJ, Ulrich D (2011) Removal of synaptic $\mathrm{Ca}(2)+$-permeable AMPA receptors during sleep. J Neurosci 31:3953-3961. CrossRef Medline

Latta F, Leproult R, Tasali E, Hofmann E, L'Hermite-Balériaux M, Copinschi G, Van Cauter E (2005) Sex differences in nocturnal growth hormone and prolactin secretion in healthy older adults: relationships with sleep EEG variables. Sleep 28:1519-1524. Medline

Lin SC, Bergles DE (2004) Synaptic signaling between GABAergic interneurons and oligodendrocyte precursor cells in the hippocampus. Nat Neurosci 7:24-32. CrossRef Medline

Linkowski P, Spiegel K, Kerkhofs M, L’Hermite-Balériaux M, Van Onderbergen A, Leproult R, Mendlewicz J, Van Cauter E (1998) Genetic and environmental influences on prolactin secretion during wake and during sleep. Am J Physiol 274:E909-E919. Medline

Mackiewicz M, Shockley KR, Romer MA, Galante RJ, Zimmerman JE, Naidoo N, Baldwin DA, Jensen ST, Churchill GA, Pack AI (2007) Macromolecule biosynthesis: a key function of sleep. Physiol Genomics 31:441457. CrossRef Medline

Mallon BS, Shick HE, Kidd GJ, Macklin WB (2002) Proteolipid promoter activity distinguishes two populations of NG2-positive cells throughout neonatal cortical development. J Neurosci 22:876-885. Medline

Mangin JM, Gallo V (2011) The curious case of NG2 cells: transient trend or game changer? ASN Neuro 3:e00052. CrossRef Medline

Maret S, Dorsaz S, Gurcel L, Pradervand S, Petit B, Pfister C, Hagenbuchle O, 
O’Hara BF, Franken P, Tafti M (2007) Homerla is a core brain molecular correlate of sleep loss. Proc Natl Acad Sci U S A 104:20090-20095. CrossRef Medline

Maret S, Faraguna U, Nelson AB, Cirelli C, Tononi G (2011) Sleep and wake modulate spine turnover in the adolescent mouse cortex. Nat Neurosci 14:1418-1420. CrossRef Medline

Marinaro C, Pannese M, Weinandy F, Sessa A, Bergamaschi A, Taketo MM, Broccoli V, Comi G, Götz M, Martino G, Muzio L (2012) Wnt signaling has opposing roles in the developing and the adult brain that are modulated by hipk1. Cereb Cortex 22:2415-2427. CrossRef Medline

Meerlo P, Mistlberger RE, Jacobs BL, Heller HC, McGinty D (2009) New neurons in the adult brain: the role of sleep and consequences of sleep loss. Sleep Med Rev 13:187-194. CrossRef Medline

Mongrain V, Hernandez SA, Pradervand S, Dorsaz S, Curie T, Hagiwara G, Gip P, Heller HC, Franken P (2010) Separating the contribution of glucocorticoids and wakefulness to the molecular and electrophysiological correlates of sleep homeostasis. Sleep 33:1147-1157. Medline

Naidoo N (2011) Potential of proteomics as a bioanalytic technique for quantifying sleepiness. J Clin Sleep Med 7:S28-S30. CrossRef Medline

Nakanishi H, Sun Y, Nakamura RK, Mori K, Ito M, Suda S, Namba H, Storch FI, Dang TP, Mendelson W, Mishkin M, Kennedy C, Gillin JC, Smith CB, Sokoloff L (1997) Positive correlations between cerebral protein synthesis rates and deep sleep in Macaca mulatta. Eur J Neurosci 9:271-279. CrossRef Medline

Nishiyama A, Komitova M, Suzuki R, Zhu X (2009) Polydendrocytes (NG2 cells): multifunctional cells with lineage plasticity. Nat Rev Neurosci 10: 9-22. CrossRef Medline

Obál F Jr, Garcia-Garcia F, Kacsóh B, Taishi P, Bohnet S, Horseman ND, Krueger JM (2005) Rapid eye movement sleep is reduced in prolactindeficient mice. J Neurosci 25:10282-10289. CrossRef Medline

Polito A, Reynolds R (2005) NG2-expressing cells as oligodendrocyte progenitors in the normal and demyelinated adult central nervous system. J Anat 207:707-716. CrossRef Medline

Porkka-Heiskanen T, Kalinchuk AV (2011) Adenosine, energy metabolism and sleep homeostasis. Sleep Med Rev 15:123-135. CrossRef Medline

Psachoulia K, Jamen F, Young KM, Richardson WD (2009) Cell cycle dynamics of NG2 cells in the postnatal and ageing brain. Neuron Glia Biol 5:57-67. CrossRef Medline

Ramm P, Smith CT (1990) Rates of cerebral protein synthesis are linked to slow wave sleep in the rat. Physiol Behav 48:749-753. CrossRef Medline

Richardson WD, Young KM, Tripathi RB, McKenzie I (2011) NG2-glia as multipotent neural stem cells: fact or fantasy? Neuron 70:661-673. CrossRef Medline

Richter-Landsberg C (2000) The oligodendroglia cytoskeleton in health and disease. J Neurosci Res 59:11-18. CrossRef Medline

Rivers LE, Young KM, Rizzi M, Jamen F, Psachoulia K, Wade A, Kessaris N, Richardson WD (2008) PDGFRA/NG2 glia generate myelinating oligodendrocytes and piriform projection neurons in adult mice. Nat Neurosci 11:1392-1401. CrossRef Medline

Selmaj KW, Raine CS (1988) Tumor necrosis factor mediates myelin and oligodendrocyte damage in vitro. Ann Neurol 23:339-346. CrossRef Medline

Seugnet L, Suzuki Y, Thimgan M, Donlea J, Gimbel SI, Gottschalk L, Duntley SP, Shaw PJ (2009) Identifying sleep regulatory genes using a Drosophila model of insomnia. J Neurosci 29:7148-7157. CrossRef Medline

Simon C, Götz M, Dimou L (2011) Progenitors in the adult cerebral cortex: cell cycle properties and regulation by physiological stimuli and injury. Glia 59:869-881. CrossRef Medline

Smyth GK (2004) Linear models and empirical bayes methods for assessing differential expression in microarray experiments. Stat Appl Genet Mol Biol 3:Article3. CrossRef Medline

Sohn J, Natale J, Chew LJ, Belachew S, Cheng Y, Aguirre A, Lytle J, NaitOumesmar B, Kerninon C, Kanai-Azuma M, Kanai Y, Gallo V (2006)
Identification of Sox17 as a transcription factor that regulates oligodendrocyte development. J Neurosci 26:9722-9735. CrossRef Medline

Spiegel K, Luthringer R, Follenius M, Schaltenbrand N, Macher JP, Muzet A, Brandenberger G (1995) Temporal relationship between prolactin secretion and slow-wave electroencephalic activity during sleep. Sleep 18: 543-548. Medline

Stevens B, Porta S, Haak LL, Gallo V, Fields RD (2002) Adenosine: a neuron-glial transmitter promoting myelination in the CNS in response to action potentials. Neuron 36:855-868. CrossRef Medline

Terao A, Greco MA, Davis RW, Heller HC, Kilduff TS (2003a) Regionspecific changes in immediate early gene expression in response to sleep deprivation and recovery sleep in the mouse brain. Neuroscience 120: 1115-1124. CrossRef Medline

Terao A, Steininger TL, Hyder K, Apte-Deshpande A, Ding J, Rishipathak D, Davis RW, Heller HC, Kilduff TS (2003b) Differential increase in the expression of heat shock protein family members during sleep deprivation and during sleep. Neuroscience 116:187-200. CrossRef Medline

Terao A, Wisor JP, Peyron C, Apte-Deshpande A, Wurts SW, Edgar DM, Kilduff TS (2006) Gene expression in the rat brain during sleep deprivation and recovery sleep: an Affymetrix GeneChip study. Neuroscience 137:593-605. CrossRef Medline

Thompson CL, Wisor JP, Lee CK, Pathak SD, Gerashchenko D, Smith KA Fischer SR, Kuan CL, Sunkin SM, Ng LL, Lau C, Hawrylycz M, Jones AR, Kilduff TS, Lein ES (2010) Molecular and anatomical signatures of sleep deprivation in the mouse brain. Front Neurosci 4:165. CrossRef Medline

Tononi G, Cirelli C (2006) Sleep function and synaptic homeostasis. Sleep Med Rev 10:49-62. CrossRef Medline

Vecsey CG, Peixoto L, Choi JH, Wimmer M, Jaganath D, Hernandez PJ, Blackwell J, Meda K, Park AJ, Hannenhalli S, Abel T (2012) Genomic analysis of sleep deprivation reveals translational regulation in the hippocampus. Physiol Genomics 44:981-991. CrossRef Medline

Vyazovskiy VV, Achermann P, Borbély AA, Tobler I (2004) The dynamics of spindles and EEG slow-wave activity in NREM sleep in mice. Arch Ital Biol 142:511-523. Medline

Vyazovskiy VV, Cirelli C, Pfister-Genskow M, Faraguna U, Tononi G (2008) Molecular and electrophysiological evidence for net synaptic potentiation in wake and depression in sleep. Nat Neurosci 11:200-208. CrossRef Medline

Vyazovskiy VV, Cirelli C, Tononi G (2011) Electrophysiological correlates of sleep homeostasis in freely behaving rats. Prog Brain Res 193:17-38. CrossRef Medline

Waters KM, Pounds JG, Thrall BD (2006) Data merging for integrated microarray and proteomic analysis. Brief Funct Genomic Proteomic 5:261-272. CrossRef Medline

Winrow CJ, Tanis KQ, Rigby AM, Taylor RR, Serikawa K, McWhorter M, Tokiwa GY, Marton MJ, Stone DJ, Koblan KS, Renger JJ (2009) Refined anatomical isolation of functional sleep circuits exhibits distinctive regional and circadian gene transcriptional profiles. Brain Res 1271:1-17. CrossRef Medline

Yokoyama TK, Mochimaru D, Murata K, Manabe H, Kobayakawa K, Kobayakawa R, Sakano H, Mori K, Yamaguchi M (2011) Elimination of adultborn neurons in the olfactory bulb is promoted during the postprandial period. Neuron 71:883-897. CrossRef Medline

Yuan X, Eisen AM, McBain CJ, Gallo V (1998) A role for glutamate and its receptors in the regulation of oligodendrocyte development in cerebellar tissue slices. Development 125:2901-2914. Medline

Yu WP, Collarini EJ, Pringle NP, Richardson WD (1994) Embryonic expression of myelin genes: evidence for a focal source of oligodendrocyte precursors in the ventricular zone of the neural tube. Neuron 12:1353-1362. CrossRef Medline

Zimmerman JE, Rizzo W, Shockley KR, Raizen DM, Naidoo N, Mackiewicz M, Churchill GA, Pack AI (2006) Multiple mechanisms limit the duration of wakefulness in Drosophila brain. Physiol Genomics 27:337-350. CrossRef Medline 